\title{
N. F. S. Grundtvig og naturalismen
}

\author{
Af Ole Nyborg
}

N. F. S. Grundtvig anvendte begreberne "Naturalisme", "Naturalister" og "naturalistisk" mange steder i sit forfatterskab. Mest kendt er hans tale om "Naturalisterne" i indledningen til Nordens Mythologi fra 1832. Grundtvigs opfattelse af naturalismen og naturalisterne er ofte i Grundtvig-forskningen blevet analyseret ud fra hans formuleringer i Nordens Mythologi. Forskningen har kun i meget begrænset omfang inddraget alle de øvrige referencer, som findes i Grundtvigs forfatterskab til "Naturalismen" eller "Naturalisterne".

\section{Indledning}

N. F. S. Grundtvigs indledning til Nordens Mythologi fra 1832 har ofte siden givet anledning til det følgende spørgsmål: Hvem er de moderne naturalister med ånd? Dette spørgsmål blev for eksempel formuleret på den følgende måde i 1988 af Grundtvig-forskeren Hans Raun Iversen:

Skal vi i dag finde de naturalister af ånd, med hvem vi kan samarbejde (...) er det ingenlunde givet, at vi først og fremmest bør søge blandt kristne (...) Og langt mindre givet er det, at anskuelsen trives bedre blandt indfødte end blandt indvandrede i Danmark (...) Vi kan ofte mødes i et afgørende fælles menneskesyn med vore indvandrere (Iversen 1988, 80).

Efter et kort afsnit om selve naturalisme-begrebet skal i det følgende først præsenteres fire bidrag fra den nyere forskning vedrørende Grundtvig og naturalismen. Derefter skal gennemgås en række eksempler på, hvordan Grundtvig i hele sit forfatterskab beskriver, forklarer og vurderer det fænomen, som han kalder "Naturalisme". Det skal især undersøges, hvordan Grundtvig rent faktisk anvender begreber som "Naturalisme" og "Naturalister", og hvilke egenskaber eller hvilke aspekter af denne naturalisme Grundtvig især tillægger betydning. I et afsluttende afsnit skal den hidtidige forskning vedrørende Grundtvig og naturalismen diskuteres i sin helhed.

\section{Naturalisme-begrebet}

Begreber som "Naturalisme" og "naturalistisk" dukker op i den europæiske litteratur i begyndelsen af det 18. århundrede. Disse begreber anvendes således flere gange af den dansk-norske forfatter Ludvig Holberg (1684-1754), og ordet "Naturalisme" er forklaret i en af tidens mest kendte filosofiske opslagsbøger, nemlig Philosophisches Lexikon, 
som første gang blev udgivet i 1726 af den tyske teolog, filosof og historiker Johann Georg Walch (1693-1775). Vi ved, at Grundtvig på et tidspunkt har anskaffet sig dette tyske opslagsværk, fordi Walchs leksikon er opregnet på den liste, som efter Grundtvigs død blev udfærdiget over hans bøger. ${ }^{1}$ J. G. Walch anfører tre eksempler på betydningen af begrebet naturalisme: (1) en overdreven tillid til det naturlige ikke-kristne menneske og tro på dets muligheder for moralsk at stræbe mod det fuldkomne, (2) en tro på en mulig naturlig gudserkendelse, en deistisk naturlig og fornuftsbaseret religion eller religiøs opfattelse, og (3) filosofien hos den nederlandske filosof Baruch Spinoza (1632-77). Walchs forklaring i filosofileksikonnet bærer tydeligt præg af, at forfatteren er stærkt kritisk over for de synspunkter, som han betegner med ordet naturalisme. I en dansk sammenhæng synes årene efter 1870 at udgøre et markant brud i brugen af ord som naturalisme og naturalister. Her bruges begreber som naturalisme og naturalistisk ofte $\mathrm{i}$ betydningen "moderne" eller "realistisk" og som en positiv selvbetegnelse af skribenter og kulturpersonligheder, der var inspireret af eller følte sig åndsbeslægtet med litteraturkritikeren Georg Brandes (18421927).

\section{Bidrag til den nyeste forskning vedrorende Grundtvig og na- turalismen}

Grundtvig-forskningen vedrørende forholdet mellem Grundtvig og naturalismen er omfattende. ${ }^{2}$ I det følgende skal gennemgås nogle vigtige forskningsbidrag fra de sidste 15 år vedrørende Grundtvig og naturalismen. De fire forskere, som skal refereres nedenfor, analyserer primært Grundtvigs udspil over for de såkaldte "Naturalister" i Nordens Mythologi fra 1832.

\footnotetext{
${ }^{1}$ J. G. Walchs Philosophisches Lexicon (Leipzig 1740), jf. Fortegnelse over den af N. F. S. Grundtvig efterladte Bogsamling (København 1873), 281, nr. 8281.

${ }^{2}$ I nærværende undersøgelse er følgende værker blevet inddraget: Nørgaard (1935, 1936, 1938), Scharling (1947), Høirup (1949), Michelsen (1956, 1965, 1972, 1988), Aronson (1960), Thaning (1963, 1965, 1966), Lindhardt (1964), Bugge (1965, 1968, 1983, 2006), Thyssen (1965, 1967, 1991), Ehnevid (1973), Elbek (1975), Jensen (1977), Prenter (1983), Grell (1980, 1988a, 1988b, 1992, 1995, 1998), Lundgreen-Nielsen (1983, 1995, 2007), Iversen (1988), Balslev-Clausen (1990), Hansen (1997), Allchin (1997), Christensen (1998, 2001), Vind (1999), Gregersen (2002), Stokholm (2003) og Pedersen (2005).
} 


\section{Bent Christensen 1998 og 2001}

Bent Christensen ${ }^{3}$ opfatter Grundtvigs initiativ i Nordens Mythologi over for naturalisterne som et værdifuldt forbillede for en senere tid. Grundtvig viser en markant åbenhed og vilje til at indgå $i$ en jævnbyrdig dialog og et fordomsfrit samarbejde med mennesker i Danmark, med hvem han er helt uenig med hensyn til kristendomssynet. I 1832 indser Grundtvig, at ethvert kulturelt samarbejde skal bygge på et fællesmenneskeligt grundlag, hvor kristne særstandpunkter ikke har nogen apriorisk vægt:

Et forbillede eller en model, der kan bruges også i senere tider med henblik på kulturelt samarbejde og sam-liv mellem kristne og ikke-kristne - og dermed også med henblik på sam-livet, sam-eksistensen overhovedet mellem kristne og ikke-kristne, på et fælles menneskeligt grundlag (Christensen 1998, 502-503).

Grundtvig når i 1832 frem til en videnskabsforståelse, hvor den videnskabelige sandhed er helt uafhængig af enhver religiøs opfattelse, og han indser, at han selv og mennesker, der er ikke-troende og helt anderledes tænkende, kan dele fælles humane værdier:

Hans videnskabsforståelse som sådan [var] ikke bundet til en enhedskultur (Christensen 2001, 211).

[Grundtvig skelnede] mellem egentlig kristen tro og så den anskuelse, som de egentlig kristne og "naturalisterne" kunne være fælles om (...) fællesskabet om anskuelsen, og dermed om kulturen og videnskabeligheden (Christensen 2001, 212.). ${ }^{4}$

Grundtvig formulerede sig begejstret om de værdier, som de kristne og naturalisterne kunne og burde have til fælles:

Når Grundtvig kan tale så stort om et fællesskab mellem kristne og ikkekristne, så bygger det netop på den skabelsesteologi, han som troende kristen har (Christensen 2001, 212).

Grundtvig forestillede sig en slags sekulær frelseshistorie i den ikkekristne verden:

${ }^{3}$ Bent Christensen (1998), Omkring Grundtvigs Vidskab. En undersøgelse af N. F. S. Grundtvigs forhold til den erkendelsesmoessige side af det kristeligt nødvendige livsengagement og (2001), "Om 'Omkring Grundtvigs vidskab"” $\mathrm{i}$ Grundtvig-Studier 2001, København, 191-220.

${ }^{4}$ Jf. Christensen 2001, 211: Efter 1832 mente Grundtvig ikke længere, at fornuften nødvendigvis skulle oplyses af troen. Fornuften kunne frembringe sand viden helt uafhængig af troen. 
Grundtvig opererer (...) med en i selve skabelsen indbygget forklaringsudvikling eller vækst, hvorigennem den menneskeslægt, der ved skabelsen var som et nyfødt barn - trods syndefaldet og dets virkninger ved tidens ende skal nå sin fulde udfoldelse. Man kan også sige, at den "forklaring", Grundtvig taler om i Indledningen til "Nordens Mythologi”, er en (...) skabelsesteologisk parallel til selve genløsnings-herliggørelsen (Christensen 2001, 212).

\section{Ole Vind 1999}

Som en af de få i Grundtvig-forskningen har Ole Vind i sin disputats Grundtvigs historiefilosofi fra 1999 peget på lighederne mellem historiefilosofien hos Grundtvig og hos G. W. F. Hegel (1770-1831). Vind fortolker Grundtvigs indledning til Nordens Mythologi som en tilnærmelse til og en form for godkendelse af den hegelske historiefilosofi:

I et historiefilosofisk perspektiv (...) er det åbenbart, hvor beslægtede Hegels og Grundtvigs historiesyn er (...) Efter 1832 blev Hegel for Grundtvig et udpræget eksempel på den naturalisme med ånd, han i sin historiefilosofi havde forsonet sig med (Vind 1999, 477).

Grundtvig udtrykte i skriftet om den tyske teologi fra $1837^{5}$ et
håb om, at Christenhedens Naturalisme vil få en kirkelig form (...) og da "maae vel Hegelianerne staae for Styret, som erkiende det historisk Givne for den nødvendige Udgangs-Punkt, de ingenlunde vil opgive men kun videnskabelig forklare". Grundtvig måtte i denne tyske sam- menhæng stå højrehegelianerne nærmest (Vind 1999, 483).

Det afgørende gennembrud i Nordens Mythologi var, at det nu blev muligt for Grundtvig at dele værdier med den hegelske historiefilosofi. Religiøst eller kristeligt havde Grundtvig intet til fælles med Hegel, men med hensyn til "Anskuelsen", altså historieopfattelsen, kunne han efter 1832 dele den med de tyske hegelianere, som var de sande naturalister med ånd:

Det var adskillelsen af tro og anskuelse, der fra 1832 muliggjorde forsoningen med den tyske historiefilosofis anskuelser. Fra 1832 repræsenterede den tyske historiefilosofi (...) i Grundtvigs syn en naturalisme med ånd, som, netop fordi den var af ånd, måtte dele den mosaiskkristelige anskuelse af menneskeslægtens historie som et udviklingsoptimistisk verdensdrama (Vind 1999, 432).

Hans forsoning med de tyske naturalister med ånd havde som forudsætning, at disse naturalister anerkendte ånden og dens historiske

${ }^{5}$ Grundtvigs tanker om naturalismen i dette skrift vil blive analyseret nedenfor s. $130 \mathrm{ff}$. 
virkninger - men blot ikke anerkendte åndens guddommelige oprindelse (Vind 1999, 560-561).

\section{Kim Arne Pedersen 2005}

Kim Arne Pedersen har i 2005 fortolket Grundtvigs udspil til naturalisterne i $1832 .{ }^{6}$ I sin konklusion taler Pedersen om Grundtvigs

åbning i forhold til naturalisterne af ånd, og (...) denne åbnings teologiskidemæssige begrundelse $i(\ldots)$ sondringen mellem kirke og skole og frihedstænkningen (...) Grundtvigs tematisering af friheden står i forbindelse med hans modernitetsbevidsthed (...) det moderne positive begreb om meningsmæssig pluralisme, som er forbundet med frihedstanken (Pedersen 2005, 116-117).

For Pedersen er Grundtvig en moderne frihedstænker, som er tilhænger af en skarp adskillelse af religiøse og alment samfundsmæssige spørgsmål. Grundtvig er en fortaler for den moderne ide om åben dialog og meningsmæssig pluralisme, og Grundtvig viser i Nordens Mythologi og i det første bind af sin Haandbog $i$ Verdens-Historien fra 1833 , at han accepterer naturalisternes værdier, tilværelsesfortolkninger, kultur- og samfundsopfattelse som legitime og ligeberettigede med sine egne værdier:

Håndbogen er blevet til på baggrund af Grundtvigs (...) invitation til samarbejde mellem kristne og naturalister af ånd i Nordens Mythologi fra 1832. Og hvis man går (...) Haandbog $i$ Verdens-Historien efter, viser det sig, at Grundtvig (...) ved siden af sin egen opfattelse [af skabelsen] stiller naturalisternes tolkning af de to beretninger [ $\left.\begin{array}{lll}i & 1 & M o s\end{array}\right]$ som myter (Pedersen 2005, 115).

Pedersen tillægger Grundtvig en bestemt form for skabelsesteologi, der indebærer, at alle mennesker er skabt i Guds billede og derfor er legitime, mulige og berettigede partnere for et kristent menneske. Pedersen synes på den måde at hævde, at Grundtvig i 1832 erklærer sig villig til at samarbejde med næsten alle andre kræfter i det danske samfund. Det er også bemærkelsesværdigt, at Pedersen mener, at den helt åbne dialog og det fordomsfri samarbejde, som Grundtvig taler om i 1832, rent faktisk føres ud i livet i Danmark fra slutningen af 1830 'erne. I Pedersens artikel er det dog ikke klart, hvad han her præcist refererer til:

Skabelsestanken gør det muligt for Grundtvig at forholde sig åbent til sin samtid, og dermed også at indlede det kultursamarbejde med natu-

${ }^{6}$ Kim Arne Pedersen (2005), "Grundtvig og fundamentalismen" i GrundtvigStudier 2005, København, 86-124. 
ralisterne af ånd, som signaleres i Nordens Mythologi 1832 og reelt indledes fra slutningen af 1830 'eme (...) Skabelsestanken udfoldes i forbindelse med menneskets lighed med Gud i henseende til det levende ord og kærligheden som grund-egenskab (Pedersen 2005, 108).

Netop, fordi Grundtvig i 1825 er nået frem til et klart kirke- og kristendomsbegreb, bliver han "fri" til at samarbejde med naturalisterne af ånd (Pedersen 2005, 116).

\section{K. E. Bugge 2006}

Lige som i sine tidligere værker (jf. nedenfor s. 141f.) fortolker K. E. Bugge (2006) ${ }^{7}$ Grundtvigs indledning til Nordens Mythologi i 1832 på den måde, at Grundtvig viser en markant åbenhed over for og en stærk villighed til at samarbejde med "anderledes tænkende". 8 Det er Grundtvigs pointe, at hvis man klart adskiller "Tro" og "Anskuelse", er der gode muligheder for et samarbejde mellem de kristne og naturalisterne:

Når sondringen mellem tro og anskuelse er gennemført, da kan kristne og naturalister "holde Skole sammen" (...) [så] må man på grundlag af de elementer i menneskesynet, man er enige om (...) på grundlag af "Anskuelsen", kunne samarbejde om løsningen af de nødvendige samfundsopgaver (Bugge 2006, 54).

Bugge fortolker Grundtvig således, at de kristne bør, skal og kan gå ind $\mathrm{i}$ en åben dialog og et fordomsfrit samarbejde med alle sådanne naturalister, som ikke specifikt hylder et fysikalistisk eller reduktionistisk menneskesyn. Ifølge Bugge ${ }^{9}$ tror Grundtvig på, at der kan skabes en "vidtgående enighed" mellem de kristne og naturalisterne:

Hvad enten man er "Christen eller Hedning, Tyrk eller Jøde", ${ }_{10}^{10}$ hedder det, må man være overbevist om, at mennesket er skabt i Guds Billede,

${ }^{7}$ K. E. Bugge (2006), "En upåagtet dimension i Grundtvigs tanker om 'Anskuelsen"” i Grundtvig-Studier 2006, København, 53-66.

${ }^{8}$ Jf. Bugge 1965, 279, Bugge 1983, 213 og Bugge 2006, 54.

${ }^{9}$ Bugge 2006, 54. - Bugge 2006, 61-62 fremhæver dog, at for Grundtvig forudsætter en sådan "vidtgående enighed", at naturalisterne også anerkender tanken om synden og ikke kun tanken om skabelsen.

${ }^{10}$ Jf. Grundtvig i US V, 400. Dette formelagtige udtryk lyder bibelsk, men er det ikke. Dets led opregnes i P. A. Heibergs satiriske samtidsroman Rigsdalers-Sedlens Hoendelser, Nr. 4, 1787, i forbindelse med en svidende ironisk katekismus med 10 bud for entreprenante købmænd, hvis eneste Gud er penge, og hvis eneste interesse er at gavne sig selv. Heiberg-teksten optrykkes i 1789 (og 1833 og 1884). Grundtvig, der i sin skoletid hos pastor Laurits Feld i Thyregod var en ivrig Heiberg-læser (jf. US I, 15), har altså taget et negativt 
samt enige om, at mennesket på et vist tidspunkt kom i misforhold til sin egentlige bestemmelse. De "hedninger", Grundtvig her tænker på, benævner han "Naturalister". Med dette udtryk mener han mennesker, der ikke er bundet af et snævert biologisk eller mekanistisk livssyn, men som har sans for, at "Aand" er en væsentlig bestemmelse ved at være menneske. "Naturalister" er (...) alle de ikke-troende (...) der har haft og har "Glimt af Aand og Gnist af Sandhedskiærlighed" (Bugge 2006, 53).

I Nordens Mythologi taler Grundtvig om, at de sande kristne og naturalisterne kan dele "Anskuelse", selv om de ikke har "Troen" til fælles. Bugge fortolker Grundtvigs begreb om denne "Anskuelse" således, at Grundtvig refererer til grundlæggende elementer i den naturlige teologi. Men oversat til nutidige begreber hævder Grundtvig ifølge Bugge, at et frit samarbejde mellem de kristne og naturalisterne er fuldt ud muligt baseret på visse almenfilosofiske og ikke-religiøse forudsætninger. ${ }^{11}$

\section{Grundtvigs brug af begreberne "Naturalisme", "naturali- stisk" og "Naturalister"}

Grundtvig anvender begreberne "Naturalisme" og "Naturalister" på et stort antal steder i sit forfatterskab.I det følgende skal gennemgås en række af disse eksempler. En analyse af Grundtvigs behandling af naturalismen i indledningen til Nordens Mythologi 1832 bør ikke adskilles fra eller anskues isoleret fra Grundtvigs mange andre referencer til og anvendelse af begreberne "Naturalister", "naturalistisk" og "Naturalisme".

\section{Grundtvigs verdenshistorie fra 1817}

Grundtvig behandler indgående naturalismen i sin Udsigt over Verdens-Krøniken fornemmelig i det Lutherske Tidsrum fra 1817. Det sker

ment udtryk og gjort det positivt i sin filosofi i NM 1832's store indledningsafsnit. Oprindeligt står der hos Heiberg "en Kristen, Jøde, Tyrk eller Hedning" (Borchsenius 1884, 65). Den bibelske stilfarve er bevidst, idet Heiberg parodierer såvel de 10 bud som katekismusformens spørgsmål og svar. Men Grundtvig tager i 1832 den hånlige identifikation af disse irreligiøse købmandsfigurer og bruger den seriøst om alle mennesker, der er potentielle åndsvæsener. Hvad han har tænkt ved formuleringen, og om Heiberg-stedet har været ham bevidst, får stå hen. Det let ændrede citat stikker måske ikke dybere end til en erindring om en flot ordkæde. (Meddelt af Flemming Lundgreen-Nielsen.)

${ }^{11}$ Bugge 2006, 62. 
især $\mathrm{i}$ forbindelse med en skildring af den franske revolution i 1789, hvori Grundtvig ser en kulmination af "Naturalismen":

Hvorledes det ene Skridt drog det andet efter sig, saa man nødtes til at indvillige i et Møde af alle tre Stænder (...), ophævede Lehns-Væsenet, gjorde Kongen til en Stats-Tjener, det vil sige til deres Stads-Tjener, og hvorledes den første Akt af Sørgespillet endte sig med Raab paa en Republik og Kongens Henrettelse, det behøver ikke her at fortælles (US III, 688).

I det naturalistiske samfund i Frankrig, som i 1790'erne afløser det feudale samfund, reduceres mennesker til umennesker og vilde dyr. Naturalismen sønderriver menneskelighedens og kærlighedens bånd:

Ligesaalidt vil vi opholde os ved de afvexlende Constitutioner og Regjerings-Navne (...) naar et Folk, der har været christnet, raser som Besatte og overgaaer de Vilde (...) At have eller søge, hvad man kalder Lykke i Verden, og at troe paa Gud og et evigt Liv, agtedes omtrent for lige store Forbrydelser (US III, 689).

Som andre steder i forfatterskabet fremhæver Grundtvig, at naturalismen gør mennesker moralsk tøjlesløse og hæmningsløse:

Horer i vellystig Dragt førde man paa Triumphvogne, satte dem paa Alteret, gjorde Røgelse og tilbad i dem Fornuftens Gudinder, som de urene Lidenskaber ogsaa hos Vantroe virkelig ere (US III, 689).

Naturalismen fører til en fysisk svækkelse af mennesker på grund af dens frihedstrang, udsvævelser og løssluppenhed. Naturalisterne ophæver den traditionelle sociale og hierarkiske orden og har en falsk opfattelse af kærligheden. De hævder, at de med deres såkaldte kærlighed elsker alle mennesker, og at et menneske bør elske alle andre mennesker som individer, uanset om disse andre mennesker er kristne eller ukristne:

Robespierre (...) erklære[de], at der dog skulde faae Lov at være en Gud og Udødelighed til (...) mat af Udsvævelser, søgte man at give Forfatningen en mere lovmæssig Skikkelse, og nu kom (...) en Slags naturalistisk Gudstjeneste i Mode, hvis Tilhængere kaldte sig Theophilanthroper og forfulgde, af Kjærlighed til Gud og Mennesken, hvem der troede mere end de (...) Statsroret vedblev at slingre fra Haand til Haand, Dyden var fredløs, Retten sad i Spydstagen, Frihed og Lighed saae man overalt i Almanakker og Aviser (US III, 689).

Naturalismen er selvklogskabens og selvrådighedens ånd. Grundtvig sammenligner forholdene i det naturalistiske samfund med forholdene på en sindssygeanstalt, hvor gale mennesker agerer irrationelt, skadeligt og selvskadeligt i deres mørke, uvidenhed og blindhed kun styret af deres medfødte naturlige drifter. Naturalismen medfører et moralsk 
forfald og en fysisk svækkelse og udtømmelse af alle sunde energier. Naturalismen er en sygdom i samfundet. Begivenhederne i Frankrig i 1790 'erne viser, hvad der sker, hvis naturalismen sejrer. Naturalismen er den største fare, som truer den traditionelle europæiske kristne civilisation i det 19. århundrede. ${ }^{12}$

\section{Grundtvig om naturalismen i 1824}

Grundtvig behandler også naturalismen i sin "Brevveksling mellem Nørrejylland og Christianshavn" fra $1824 .{ }^{13}$ Grundtvig fortæller her, hvordan han som ung student på Københavns Universitet blev en ivrig tilhænger af naturalismen:

at jeg, som Student, ei blot strax henreves af Strømmen, og kaarede en Tanke-Gang, der forde dristig Frihed i sit Skjold, men tilegnede mig den $i$ hele sin Udstrækning, og var en af dens ivrigste Forfægtere (US IV, 230).

Men han blev hurtigt klar over naturalismens falskhed. Den taler ivrigt om individ og frihed, men den er kun forførelse. Den hævder i sin individualisme og skepticisme, at det enkelte menneske kun skal stole på sine egne tanker. Naturalismen er på den måde vilkårlig og i strid med "Tænkningens evige Love". Med dette udtryk refererer Grundtvig antageligt til sine principper om modsigelsens grundsætning. Men vel også til de tanker om naturalisterne, som han udtrykker andre steder i forfatterskabet: De vil være deres egne herrer, fædre og mestre. De vil ikke anerkende, at der findes nogen autoritet, som er højere end det enkelte individ og dets forstand og fornuft. De benægter det, som Grundtvig opfatter som den naturlige orden og de naturlige love i den skabte verden. Naturalismen drives af indbildskhedens, oprørskhedens, selvklogskabens og selvrådighedens ånd:

Jeg veed derfor ogsaa af egen Erfaring, hvad det virker paa Hoveder, som ei er bedre end mit (...) at være midt inde i den naturalistiske Tankegang, som man kalder den fri (...) [nemlig] at man i den kun bryder sig lidt om Tænkningens evige Love, men sætter dristig sit eget Tykke, som en ufeilbar Overbeviisning, mod alle Love (US IV, 230).

Naturalisterne, som Grundtvig beskriver som en slags kantianere, ${ }^{14}$ kritiserer i 1820'erne Grundtvig for at være ensidig og derfor en fjende

${ }^{12}$ US III, 689.

13 "Af Brevveksling mellem Nørrejylland og Christianshavn", 1824, US IV, 230. Denne tekst blev først publiceret fra og med år 1900 af Holger Begtrup, og titlen er ikke Grundtvigs egen.

${ }^{14}$ Jf. US VII, 697. 
af den moderne videnskab og oplysning. De hævder, at en sand videnskabelighed skal være objektiv, ikke kontekstuel og uafhængig af traditionen og det historisk givne. Ifølge dem skal den sande oplysning udgå fra den abstrakte fornuft. I 1824 afviser Grundtvig denne naturalistiske erkendelses- og videnskabsteori. En sand oplysning og videnskabelighed skal netop tage udgangspunkt i en "christelig Synsmaade". Grundtvig peger på denne måde på en kløft mellem sin egen og naturalisternes opfattelse af viden og videnskab. De synspunkter, som Grundtvig her anlægger på videnskaben, svarer til hans senere formuleringer i indledningen til Nordens Mythologi i 1832 (jf. nedenfor) $)^{15}$ :

Da jeg siden har lært, hvortil en christelig Synsmaade driver, maa jeg i det Mindste nødvendig smile, naar man [naturalisterne] snakker om den christelige Eensidighed, som en Hindring for sand Oplysning og videnskabelig Grundighed (US IV, 230).

Grundtvig angriber naturalisterne for deres naive tillid til det naturlige menneske og deres tro på det skabte menneskes naturlige eller potentielle godhed. Naturalismen bygger kasteller i luften med en falsk form for opfattelse, som benægter, at menneskets natur og karakter er fordærvet af synden. Grundtvig er enig med naturalisterne om, at Guds evige lov skal opfyldes, og han er enig med naturalisterne om, at denne lovens opfyldelse er det eneste, som betyder noget. Men Grundtvig hævder, at naturalismen på grund af sin statiske og naive tro på det naturlige menneske umuliggør, at jordens mennesker kan udvikles til at opfylde loven og realisere den kærlighed, som er opfyldelsen af "Guds evige Lov":

Det er idel Vind, Alt hvad man fortæller om vore naturlige Kræfter til at fyldestgiøre Reenheds og Kiærligheds uforanderlige Lov, (...) det er tankeløs Efter-Snakken, eller nedrig Bagtalelse, at man, ved Tro paa Frelseren, bliver enten ligegyldig mod Loven eller svagere til at opfylde den (US IV, 230).

\section{Religionsfriheden og naturalisterne i 1827}

I Grundtvigs skrift "Om Religions-Frihed" fra 1827 spiller hans opfattelse af naturalismen en fremtrædende rolle. Han henviser her til den moderne samfundsfilosofi fra det 18. og 19. århundrede med dens krav om menneskerettigheder og religionsfrihed. Tilstanden i 1827 i den

${ }^{15}$ I Det Danske Fiir-Kløver fra 1836 formulerer Grundtvig også tanken om den nødvendige ensidighed, partiskhed og kontekstuelle dimension i enhver viden, oplysning og videnskab. Jf. Bugge 1968, II, 7, 8, 9, 10, 11, 32, 33 og 50 . 
danske statskirke opfatter Grundtvig sådan, at det naturalistiske parti er blevet helt dominerende. Selv om disse naturalister ifølge deres egne idealer burde støtte kravet om den religiøse eller kirkelige frihed, har de oprettet et despoti, hvor de undertrykker og forfølger alle andre kirkelige retninger end deres egen.

Grundtvig søger på den måde at bruge naturalismen imod dens egne tilhængere, og han retter følgende appel til naturalisterne i statskirken:

Hjelp I os at oplyse Sagen for den verdslige Øvrighed, beed Den om Religions-Frihed! (US V, 53).

De danske naturalister er uærlige og hykleriske opportunister. Reelt ønsker de ingen frihed, men kun kontrol og herredømme. Grundtvigs vurdering af naturalisterne i 1827 svarer til hans vurdering af de franske naturalister i 1790'erne: Naturalismen skriger på umistelige menneskerettigheder, lighed og frihed, men ender i despoti og tyranni:

Medens derfor lovstridige Naturalister fortælle os, at Prasterne, hvad de saa end prædike, udgiøre et af Staten priviligeret Læremester-Laug, som Ingen maa modsige, Ingen unddrage sig fra til egen Opbyggelse, end sige da til en anden Gudsdyrkelse, uden at han bør angives, stævnes og dømmes efter de strængeste Forordninger (...) medens Naturalisterne (...) anprise den Religions-Tvang, deres vise Mestere fordømme (...) ja, medens Fornuftens og Frihedens Lovtalere saaledes aabenbar ere Ufornuftens og Aands-Trældommens Talsmænd (US V, 54-55).

På overfladen er naturalisterne på rette spor, når de i teorien går ind for frihed på det religiøse område, men reelt er de ifølge Grundtvig bedragere og farisæere. Naturalismen er i sine virkninger moralsk opløsende, fordi den forfører mennesker til uærlighed:

Hvad har vi at frygte, naar Herren er med os, og hvorledes kan vi, som oplyste Christne, høre Verdens Vise udvikle den store Sandhed om Troens fri Natur, og Religions-Tvangens Strid saavel mod sund Fornuft, som mod Menneskets umistelige, uskadelige, ja hvert Borger-Samfund gavnlige Aands-Rettigheder, om disse Ting, og om den Grund-Fordærvelse, det er at vænne Folk til Leg med Ord (...) i de vigtigste og helligste Anliggender, hvor kan vi høre Sligt, uden med det Samme at høre vor Mester raabe: giør som de [de skriftkloge ogfarisceerne] sige, men ei som de giøre; thi de sige det vel, men giøre det ikke! (US V, 54; jf. Matt 23,3).

Grundtvig lægger stor vægt på, at det naturalistiske parti i statskirken optræder lovstridigt og undergravende i forhold til den legitime danske statsmagt. De sande kristne er derimod en faktor i det danske samfund, 
som kan virke bevarende og understøttende for den bestående sociale og moralske orden:

Uagtet derfor vore Dages Naturalister (...) aldrig have bedet Øvrigheden om den Religions-Frihed, Stats-Lovene nægter dem, ja, uagtet de, i det nittende Aarhundrede, ikke synes at føle mindste Betænkelighed ved at love den Stats-Religion, de vil nedbryde, deres tro Tjeneste, slet ikke synes at ville nøies med ringere Frihed, end den himmelraabende at maatte forføre de Christnes Børn fra deres Fædres, i Staten fredlyste Tro (...) saa maae vi christelige Præster dog ingenlunde lade os smitte af saa slette Exempler (US V, 54).

Grundtvig vurderer i 1827 i høj grad naturalismen ud fra den centrale statsmagts og ud fra den bestående sociale ordens synsvinkel. Grundtvig taler også på den måde om den religiøse tilstand i hele Europa. Naturalismen har forstyrret den "Rolighed", som er nødvendig for de kristne europæiske staters lykke og fremgang. Den er oprørsk og undergravende i sine virkninger:

Det er nemlig umueligt Andet, end at enhver opmærksom Regiering har maattet finde, og maa befinde sig i stor Forlegenhed, ved den religiøse Giæring, som, især fra Midten af forrige Aarhundrede, har meer og mindre forstyrret Roligheden vidt og bredt i Christenheden (US V, $55)$.

De naturalistiske prædikanter er en slags subversive muldvarpeagenter. Der bør etableres en kirkelig tilstand, som gør det muligt for den centrale statsmagt at skride ind over for ulydige og oprørske prædikanter. De er ifølge Grundtvig kongens embedsmænd og redskaber, og kongen bør kunne stole på sine betroede mænd, ellers ophæves enhver social orden i staten. Grundtvig beskriver i 1827 den ideale kirkeordning i den ideale stat således:

Havde Enkelte af Stats-Kirkens Modstandere da indsneget sig i Dens Lære-Embeder, vilde de snart blevet bortfjernede uden al anden Uleilighed, end den, en Stat altid maa have med enkelte utroe og selvraadige Embeds-Mænd (US V, 55-56).

Naturalismen og det tyranni, som naturalisterne har etableret, er til fare for den enevældige statsmagt. Naturalismens stats- og samfundsopfattelse er det modsatte af en "oplyst" tanke om samfundet og staten. Grundtvig anskuer og vurderer i høj grad naturalismen ud fra en politisk eller samfundsmæssig synsvinkel. Han taler således om:

det smerteligste Aands-Tyranie, det er Altsammen Noget, vist ingen oplyst Statsmand kan dølge for sig selv, eller, med Blik paa Fremtiden betragte uden Gru (US V, 56). 
Naturalisterne bestrider den herskende religiøse orden og undergraver den legitime statsmagt. Virkningen af deres forkyndelse er, at den danske stat og det danske kongerige bliver et hus i splid med sig selv (Matt 12, 25, jf. US V, 58). Den centrale statsmagt bør gennemføre en reel kontrol med, at statskirkens prædikanter ikke bedriver statsfjendtlig virksomhed. Statskirkens præster er af den enevældige landsfader sat til at udfylde en bestemt og af statsmagten fastlagt funktion. Grundtvig beskriver forfærdet, hvordan

mange af Lærerne i Stats-Kirken selv bestride [bekcemper] den Religion, de sættes til at forkynde. At en saadan Lovstridighed i Kirken, og Selvmodsigelse i Staten, maa i Tidens Længde blive fordærvelig, at det kun er Selvbedrag, naar Staten enten i offenlige eller private Forhold troer sig sikkret ved Eeds-Formularer $(U S \mathrm{~V}, 56)$.

\section{Nordens Mythologi fra 1832 og "Naturalismen"}

Grundtvig taler flere steder om "Naturalisterne" og "Naturalismen" i indledningen til Nordens Mythologi fra 1832. Begreberne "Naturalister", "Naturalisme" og "naturalistisk" optræder kun i indledningen og ikke i selve den efterfølgende fremstilling af den nordiske mytologi.

Grundtvig har i denne indledning to pointer. Den ene pointe er, at den rene naturalisme er en menneske-, samfunds- og livsopfattelse, som er helt uantagelig for de sande kristne. Den anden pointe er, at der er mulighed for en samtale og et samarbejde mellem de sande kristne og de nordiske naturalister, hvis disse naturalister på visse punkter opgiver deres egentlige hårdnakkede naturalisme og viser sig imødekommende over for de sande kristnes forestillinger om samfund, menneske, kultur og kristentro.

Grundtvig formulerer sin centrale tese vedrørende sit forhold til naturalisterne således:

Derfor har jeg det velgrundede Haab, at alle Nordens Naturalister, med Aand, vil af alle Kræfter være os behjelpelige til at faae det store SkoleGiftermaal istand: mellem Forstanden og den Dramatiske Poesi (US $\mathrm{V}, 435)$.

Det er værd at lægge mærke til, at Grundtvig her ikke taler om "naturalister med ånd" - således som det ofte er blevet hævdet i Grundtvig-forskningen - eller om, at der findes naturalister, som "har ånd". Det, som Grundtvig ordret siger, er, at han håber på, at nogle af naturalisterne trods alt i praksis kan reagere med ånd $\mathrm{i}$ forhold til de kristnes projekt. De fleste steder i Grundtvigs beskrivelser af natura- 
listerne fremgår det, at han mener, at naturalisterne er åndløse og altså egentlig ikke har ånd. ${ }^{16}$

I det ovenstående citat er det tydeligt, at det projekt, som Grundtvig omtaler som det nødvendige "Giftermaal", egentlig ikke er naturalisternes, men de sande kristnes projekt. Grundtvig beder naturalisterne om med velvilje at støtte de sande kristnes projekt, der i al fald ifølge hans opfattelse skal frelse det danske og de nordiske samfund. ${ }^{17}$ Grundtvig forestiller sig ikke, at naturalisterne skal bidrage med deres synspunkter til et eventuelt fælles projekt. Det projekt, som Grundtvig taler om, findes allerede udformet hos de sande kristne. Det, som naturalisterne skal eller kan bidrage med, er en støtte til de kristnes nydanske og gammeldanske projekt for Danmark og Norden. Grundtvig viser ikke i Nordens Mythologi en vilje til at indgå i et slags kompromis med naturalisterne på den måde, at et fælles projekt kan bestå af tanker fra de sande kristne og fra naturalisterne.

Grundtvigs formuleringer viser også, at han er bevidst om, at mange naturalister sandsynligvis ikke vil være tilbøjelige til at støtte hans projekt. Men Grundtvig forestiller sig, at der dog i Norden kan findes naturalister, som på trods af deres naturalisme vil støtte de sande kristnes projekt for kulturen og fædrelandet.

Grundtvigs tale til "Naturalisterne" i indledningen til Nordens Mythologi er tydeligt foranlediget af, at han mener, at samfundet befinder sig i en krise. Norden trænger nu i de aktuelle meget "urolige Dage" til en åndelig opvækkelse. Udtrykket om de urolige dage kan referere til den franske julirevolution i $1830 \mathrm{og}$ til det kongelige danske reskript fra maj 1831, som bestemte, at der skulle indføres rådgivende stænderforsamlinger. Vi ved i dag, at netop disse to begivenheder satte gang i den liberale bevægelse i Danmark:

Derfor er jeg vis paa, at naar man vaagner i Norden, og vaagne maae alle gamle Folk i vore urolige Dage, da vil Mange laane Øre til den Tale, at den Mosaisk-Christelige Anskuelse være nu (...) oprundet paa naturlig eller overnaturlig Maade, saa er det den eneste cegte Grund-Anskuelse af Menneske-Livet (US V, 401).

\footnotetext{
${ }^{16}$ Jf. for eksempel US VII, 696-697.
}

${ }^{17}$ Grundtvig henvender sig til naturalisterne på en analog måde i 1827 (jf. ovenfor) og i 1832 . I 1827 beder han dem om at anmode statsmagten om at gennemføre den religiøse eller kirkelige frihed, der ifølge Grundtvig i det væsentlige er et projekt, som de sande kristne er interesseret i. I 1832 appellerer han på en tilsvarende måde til naturalisterne om at give deres støtte til de kristnes folkelige opvækkelsesprojekt, der skal imødegå de foruroligende og uroskabende tendenser i samtiden. 
En nydansk og oldnordisk bevægelse i Danmark eller i Norden skal genopvække folkelivet og folkeligheden. Grundtvig er i Nordens Mythologi bevidst om, at den renlivede naturalisme måske er skeptisk over for hans tanker om folkelivet og folkeligheden, men Grundtvig forestiller sig, at der i Norden kan findes naturalister, som på det punkt vil modificere deres naturalisme og støtte en vækkelse af folkelivet og folkeligheden. Grundtvig ønsker - eller håber, at det for de sande kristne er muligt - at gå i dialog med og samarbejde med nogle af de nordiske naturalister, men under den forudsætning, at de giver afkald på dele af deres renlivede naturalisme:

Enten Man nemlig er Christen eller Hedning (Naturalist), kan Man dog umuelig være Historiker, med Glimt af Aand, uden strax at see (...) at det er den alene [den højere kristelige anskuelse] som har givet den ny Folke-Verdens Tanke-Gang, Dannelse og Vidskab det Universal-Menneskelige Præg, som den gamle Verden fattedes, og som selv Roms Uvætte ei har mægtet at udslette, men kun at misbruge (US V, 399-400).

Grundtvig beskriver i Nordens Mythologi sit samfundsmæssige projekt, som han inviterer nogle af naturalisterne til at støtte, som en nydansk eller gammeldansk udvikling og som en genindførelse af værdierne fra den oldnordiske verden, således som Grundtvig konstruerer disse værdier:

Naar jeg (...) taler om en $\mathrm{Ny}$-Dansk Udvikling, da tager jeg ikke det Danske Navn i den indskrænkede Bemærkelse (...) men i den OldNordiske, da det udstrakde sig (...) til de Nordiske Udfløttere paa Herkules-Øen. Ligeledes, naar jeg taler om Gienfødelsen af en Christelig og Gammel-Dansk Videnskabelighed, da mener jeg (...) ikke heller noget Christeligt, der er bundet til den Christne Troe, men en GraeskNordisk Udvikling, som, ved Hielp af den Mosaisk-Christelige GrundAnskuelse, bliver levende og Universal-Historisk (US V, 399).

Grundtvig udtrykker et håb om, at det måske kan vise sig muligt, at de sande kristne kan gå i dialog med og samarbejde med nogle af naturalisterne - nemlig med de naturalister, som over for de kristne kan og vil demonstrere, at de kan handle og virke med "Aand".

Det følgende citat forklarer, hvad denne betingelse indebærer: Grundtvig vil gå i dialog med sådanne naturalister, som anerkender beretningen om Adam og hans syndefald, og som anerkender, at det jordiske menneske er en falden skabning, som er fordærvet af et syndefald, som engang er sket som en historisk begivenhed. ${ }^{18}$ I forhold til den beskrivelse, som Grundtvig selv giver af naturalisterne i Nordens

${ }^{18}$ At Grundtvig faktisk i Nordens Mythologi stiller dette radikale krav til naturalisterne, fremgår ikke klart af Bugge 2006, 61-62. 
Mythologi, må dette krav til naturalisterne virke overraskende. Grundtvig beskriver i Nordens Mythologi en "Naturalist" som et menneske, der netop benægter syndigheden og syndefaldet som et pludseligt brud i menneskehedens historie. Grundtvig udtrykker med andre ord, at han er villig til - og tror på muligheden af - en samtale og et samarbejde med naturalisterne, hvis de afsværger deres naturalisme på et afgørende punkt. Grundtvigs udspil i Nordens Mythologi er derfor ikke et reelt udspil til, hvad de fleste i dag vil opfatte som en åben dialog:

At Natur-Mennesket [Adam] er skabt i Guds Billede og havde i Guds Livs-Aande Alt hvad han behøvede til at naae sin store Bestemmelse som en Guds Søn, ${ }^{19}$ derom maae alle Mennesker med Aand være enige, og at der meget tidlig er tilstødt ham et stort Uheld, der bragde (...) Menneske-Naturen i Vilde-Rede, det bevidner baade den daglige og den Universal-Historiske Erfaring for høit og klart, til at noget Menneske med Glimt af Aand og Gnist af Sandheds-Kiærlighed kan nægte det (US V, 401).

De Christne troe nemlig, at Menneske-Naturen ved Faldet er blevet saa fordærvet, ${ }^{20}$ at al egenlig Helbredelse er umuelig (...) Dette kan Naturalisten umuelig uden grov Selv-Modsigelse indrømme, men maa erklære den Tro for en grov Mis-Forstand (...) saa han maa tvertimod paastaae, at den gamle Menneske-Natur baade kan og skal lade sig helbrede (US V, 402).

\section{Det Danske Fiir-Klover fra 1836}

Grundtvigs skrift om Det Danske Fiir-Kløver fra 1836 er det ene af i alt kun to eksempler på værker fra årene 1833-38 - altså i de seks år, som fulgte efter Nordens Mythologi - hvor Grundtvig overhovedet omtaler "Naturalismen" eller "Naturalisterne". Dette skrift indeholder ingen spor af, at han i 1832 skulle have opnået en ny positiv opfattelse af naturalisterne, og er på ingen måde præget af nogen venlig imødekommenhed over for dem. Grundtvigs pointe i 1836 er tværtom en skarp kritik af naturalismen og en fremhævelse af den sande kristne kirkes styrke og opgaver netop på de punkter, hvor naturalismen svigter. Det Danske Fiir-Kløver rummer ingen forestillinger om, at de

\footnotetext{
${ }^{19}$ Grundtvig beskriver ikke her egenskaberne hos det nutidige menneske på jorden, men Adams egenskaber før syndefaldet.

${ }^{20}$ Jf. Michelsen 1956, 233, der fremhæver, at Grundtvig i Nordens Mythologi siger, at den menneskelige natur er ødelagt og fordærvet af syndefaldet og syndigheden. Michelsen fremhæver, at det netop var Grundtvigs syn på menneskenaturen, som adskilte ham fra naturalisterne.
} 
sande kristne kan, bør eller skal indgå i en samtale eller i et samarbejde med naturalisterne.

Grundtvig taler i 1836 om den "Nordiske Naturalisme" på en måde, som synes at indebære, at hvis han tidligere nogen sinde har troet på et samarbejde med denne, har han i al fald nu opgivet håbet.

Den nordiske naturalisme ejer ikke nogen evne eller kraft til at forædle, forbedre, udvikle eller opdrage den menneskelige natur. Grundtvig taler i Det Danske Fiir-Kløver eksplicit ikke om den kristelige eller guddommelige vækst i menigheden. Han taler om den almene menneskelige natur. Naturalismen er magtesløs over for den afgørende samfundsmæssige opgave, som netop består i at forbedre, forædle og opdrage folket. Det, som tiden og forholdene kræver, er ikke en naiv tillid til det naturlige menneske, som man kan finde hos tidens naturalister, men en magt, evne og kraft til at løfte, opdrage, forandre og forædle det danske og de nordiske folk. Kun den sande kristne kirke med dens troende medlemmer og præster kan redde Danmark ud af krisen, styrke moralen og kærligheden hos de danske undersåtter, forsvare den danske stat og understøtte det gode faderlige styre i Danmark. Grundtvig udtrykker sin centrale tese i Det Danske FiirKløver vedrørende naturalisterne på følgende måde:

Hvad nu først det tvungne Kirke-Væsen angaaer, da er Tvangen vist nok til uberegnelig Skade for Folke-Livet, men til umiddelbar Gavn for det vil Kirken dog heller ikke i sin fri Virksomhed blive; thi den Christne Kirke er kun beregnet paa Menneske-Naturen i det Hele, og den Nordiske Naturalisme har uigenkaldelig tabt sin levende Kirke-Form. Da Christendommen imidlertid, med sin mageløse Kraft til at hæve og forædle Menneske-Naturen, der indslutter alle ædle Folke-Naturer i sig, ingensteds har fundet det saa hjemligt som i Danmark, vil Den sikkert endnu ad en Omvei giøre den Danske Natur væsenlige Tjenester (Bugge 1968, II, 29).

\section{Naturalismen og den tyske teologi i 1837}

Artiklen "Den Christne Kirke og den Tydske Theologi" fra 1837 er det andet eksempel fra Grundtvigs værker 1833-38, der på nogen måde eksplicit berører naturalismen. Heller ikke denne artikel bærer præg af en tilnærmelse.

Naturalisterne er "naturlig raisonnerende Lilleputter". ${ }^{21}$ De er produkter af og udtryk for en "antichristelig Stemning" og fjender af "al Fromhed, Tro og ægte Gudsfrygt". Naturalisterne repræsenterer "Verden" og møder altid kristendommen med en "Krigs Erklæring".

${ }^{21}$ US VIII, 162. 
De pønser kun på at overvinde og tilintetgøre den kristne kirke og den kristne tro. Naturalismen "er endnu mere flau end latterlig". Den er udtryk for en falsk "Videnskabelighed" og søger at nedbryde og opløse alle værdier. Den gør mennesker mistroiske, selvkloge og forvirrede. ${ }^{22}$

I artiklen beskriver Grundtvig tre "Penne-Feider", som i 1837 pågår i Tyskland. Allerede Martin Luther i det 16. århundrede kæmpede imod naturalismen, men i det 19. århundrede er kampen blevet ulige hårdere. Mens naturalismen var svag i det 16., er den blevet en forfærdelig trussel i det 19. århundrede:

Alle Tre [pennefejder] er nu vel i Grunden Oldsager fra det Sextende Aarhundrede, men Kræfterne er i det Nittende aabenbar langt anderledes fordeelte, saa Rationalismen eller Naturalismen, som løber ud paa Eet, er nu i Tydskland alt Andet ligesaa overlegent, som den i det Sextende Aarhundrede var det underordnet (US VIII, 162).

Grundtvig lægger i artiklen klar afstand til tidens naturalisme, men han foretager det tankeeksperiment, at man kan se tidens kulturelle og teologiske problemer fra naturalisternes side. Hvis man gør det, hævder han, at naturalisterne bør tilslutte sig den hegelianske samfunds- og historieopfattelse. På en indirekte måde antyder Grundtvig, at der kan være ligheder mellem hans egen samfunds- og historieopfattelse og den hegelianske:

Skal imidlertid en saadan mythechristelig [naturalistisk] Kirke kunne stiftes og have nogen historisk Virkning, da maae vel Hegelianerne staae for Styret, som erkiende det historisk Givne for den nødvendige Udgangs-Punkt, de ingenlunde vil opgive men kun videnskabelig forklare (US VIII, 168).

En af tankerne i Grundtvigs artikel fra 1837 bliver en i høj grad betinget anerkendelse af hegelianismen. Grundtvig opfatter nemlig denne som en del af den naturalisme, hvis grundsubstans han fuldstændigt tager afstand fra. Men han skildrer dog den hegelianske naturalisme som en mindre forkastelig form. ${ }^{23}$ Den har en sandere eller mindre falsk forståelse af ånd, menneske og samfund end naturalismen hos Voltaire, Rousseau eller Montesquieu, ${ }^{24}$ som er ahistorisk, abstrakt og samfundsopløsende:

\footnotetext{
${ }^{22}$ US VIII, 162-163.

${ }^{23}$ Jf. nedenfor om Grundtvigs tvetydige vurdering af calvinismen. Såvel hegelianismen som calvinismen er ifølge Grundtvig del af den almene naturalisme, men de repræsenterer dog hver på sin måde en mindre forkastelig eller mindre skadelig form for naturalisme.

${ }^{24}$ Jf. US VII, 697.
} 
Hegelianerne har ogsaa godt indseet det, at denne Historie [Kristi historie] ei giør Naturalismen mindste Afbræk, da det egenlige StridsSpørgsmaal mellem den og gammeldags Christendom ingenlunde er, hvad der skedte engang i gamle Dage, og maatte skee, for at Menneskeheden kunde naae sit Maal, men deels efter hvilke Love det skedte, og deels i hvilket Forhold vi maae staae til det historisk Givne for at naae Maalet (US VIII, 169).

Ole Vind har peget på denne sammenhæng mellem Hegel og Grundtvig, som blandt andet kommer til udtryk i Grundtvigs artikel fra 1837. Man kan dog indvende følgende imod Vinds opfattelse: (1) Grundtvig tager i 1837 klart afstand fra naturalismen som sådan, (2) Grundtvig foretager et slags tankeeksperiment, hvor han sætter sig i naturalisternes sted, og (3) Grundtvigs tekst fra 1837 indeholder ikke én eneste reference til hans tanker om naturalisterne fra 1832. I Grundtvigs artikel er der ikke noget eksplicit tegn på, at han her skulle forklare eller have til hensigt at forklare, hvad han fem år tidligere skrev om naturalisterne i Nordens Mythologi.

\section{Grundtvigs åbne vennebrev fra 1839}

Grundtvig gør også rede for sin opfattelse af "Naturalismen" og "Naturalisterne" i sin pjece Aabent Vennebrev til en Engelsk Proest fra 1839. Han anvender i dette skrift klart begreberne "Naturalisme" og "Rationalisme" som synonymer og hævder, at den dominans, som naturalisterne opnåede i Danmark i 1790'erne, besidder de stadig i 1839. Naturalisterne er i dette vennebrev bestemte rationalistiske teologer eller prædikanter i den danske statskirke og ikke mennesker, som på en ubestemt måde er tilhængere af en mere almen eller ikke-religiøs eller i princippet ikke-kristen opfattelse eller filosofi. Der er ikke i Grundtvigs tekst nogen reference til, at han i 1832 skulle have søgt en tilnærmelse til det naturalistiske parti. Der er heller intet i dette skrift, som antyder, at Grundtvig skulle være interesseret $i$ en dialog eller i et samarbejde med disse såkaldte naturalister. Grundtvig er entydigt fordømmende over for naturalismen, som han karakteriserer med et dramatisk bibelsk udtryk og forbinder med den højeste form for gudsbespottelse (jf. Matt 24,15 og Daniel 9,26-27):

[Jeg blev] som en Bogorm fra Barnsbeen (...) tidlig bekiendt med StatsKirkens forvirrede Tilstand; men skiøndt jeg godt vidste, at det Naturalistiske Parti blandt Præsterne i det Nittende Aarhundredes Begyndelse fik en afgjort Overvægt, faldt det mig dog aldrig ind, at det nu skulde være Orthodoxerne formeent (...) at beklage hvad der i deres Øine maatte være en Ødelæggelsens Vederstyggelighed (...) De [naturali- 
sterne] (...) meende, jeg burde været udelukt fra al Adgang til PræsteEmbede i Stats-Kirken (US VIII, 194).

\section{Grundtvigs verdenshistorie, III, 1843-56.}

Grundtvig beskriver i sin Haandbog $i$ Verdens-Historien III naturalismen i tiden fra det 16. til det 18 . århundrede. ${ }^{25}$ Han anvender her som andre steder ordene "Rationalisme" og "Naturalisme" som refererende til de samme fænomener. Naturalisterne er individualister, som bekæmper den synlige nedarvede sociale orden både i kirken og i de verdslige samfund.

Grundtvig anlægger her en tvetydig vurdering af calvinismen. På den ene side var den et karakteristisk udtryk for naturalismen. På den anden side var den især i Frankrig med sin sociale og religiøse tugt, revselse og disciplinering med til at dæmme op for den rabiate naturalisme:

Ligeledes maa man fra den Borgerlige Side berømme Kirke-Tugten, der udmærkede Calvinismen (...) Den skarpe Kirketugt gjorde megen $u d$ vortes Nytte (US VII, 594).

Når Grundtvig i sin verdenshistorie forholder sig til naturalismen, er det tydeligt, at han lægger en afgørende vægt på dens moralske og samfundsmæssige eller politiske egenskaber. Grundtvig opfatter naturalismen som en umoralsk og oprørsk samfundsopløsende ideologi. Naturalismen nedriver de traditionelle moralske bånd mellem mennesker. Den "platte og flade Naturalisme" er den naturalisme, som sejrer ved revolutionerne i 1776 og 1789, og som i Grundtvigs øjne er et udslag af ukærlighedens, umoralens, selvrådighedens og oprørskhedens ånd. ${ }^{26}$ Naturalismen har truet de europæiske kristne stater siden det 16. århundrede, og den undergraver respekten for de moralske normer, bånd og dyder:

Da Calvinismen ingensteds fortrængde noget Dybere og Bedre end den selv var, men forsinkede, hvor den fik Magt, den platte og flade Naturalisme og Rationalisme (...) saa maa idetmindste Stats-Historien glæde sig ved den. Vistnok bar den Calvinistiske Selvklogskab, Selvraadighed og Herskesyge i Tidens Længde ogsaa for det Borgerlige Selskab bittre Frugter, men man maa huske, at disse Udyder skabdes ingenlunde af Calvin, men bekæmpedes meget mere af ham, saavidt det med

${ }^{25}$ Dette verdenshistoriske værk i tre bind har på sine titelblade undertitlen: "Efter de bedste Kilder. Et Forsøg af Nik. Fred. Sev. Grundtvig, Præst".

${ }^{26}$ Jf. Grundtvigs verdenshistorie-tillæg fra 1869, US VII, 695. 
Naturens Kræfter lader sig giøre, og fik ved ham den (...) borgerlig talt, uskadeligste Retning, de kunde modtage (US VII, 593-594).

\section{Grundtvigs tillæg til sin verdenshistorie fra 1869}

Den mest omfattende beskrivelse, vurdering og forklaring, som Grundtvig gav af det, som han kaldte "Naturalisme", findes i et tillæg til verdenshistorien fra 1869. Denne tekst er interessant, fordi den skrevet så sent som i 1869 - synes at være en sammenfatning af et langt livs beskæftigelse med det, Grundtvig betegnede som "Naturalismen". De udtryk, som Grundtvig i 1869 anvendte om naturalismen, genfindes mange andre steder i hans forfatterskab. Naturalismen er den moderne ånd, som truer den europæiske civilisation. Tillægget viser tydeligt, at når han anvender begreber som "Naturalisme", "Naturalister" og "naturalistisk", lægger han en afgørende vægt på deres moralske og samfundsmæssige eller politiske aspekter. Naturalisterne har en naiv og alt for optimistisk opfattelse af og tillid til det naturlige og til det naturlige menneske. Naturalismen er ukristelig og ugudelig på grund af dens tillid til det naturlige menneske og dens fornægtelse af, at mennesket er en falden skabning, hvis natur er blevet besmittet og fordærvet ved syndefaldet.

Naturalismen er tids- og verdensånden, som manifesterer sig i de amerikanske oprørsmænds selvklogskab og selvrådighed i 1776. Naturalismen er den romerske ånd og hænger sammen med den moderne frihedstænkning, de moderne samfundsteorier, de republikanske idealer og oprøret imod det traditionelle samfund. Det amerikanske oprør i 1776 er i Grundtvigs verdenshistorie et dumdristigt, barnagtigt og trodsigt brud på de evige love, som ligger immanent i historien og $\mathrm{i}$ skabelsen. Grundtvig fremstiller det 18. århundredes USA som en naturalistisk, kunstig, ahistorisk, unaturlig, åndløs og ugudelig statsdannelse. Denne statsdannelse er netop "akavet", dvs. unaturlig, klodset og forkert. Det gode ideale samfund er på den måde et alternativ til det 18. århundredes Rusland og USA, som hver på sin måde er manifestationer af en falsk naturalistisk ånd og samfundsfilosofi:

Det attende Aarhundrede, som i Verdenshistorien strækker sig fra Ludvig den Fjortendes Død (1715) til Napoleons Fangenskab (1815), bør vist nok kaldes Naturalismens Hundredaar, ei blot fordi Naturforgudelsen var dets ugudelige Kiendemærke, men fordi i dets Løb to ny Stater uden alle historiske Forudsætninger akavet hævede sig til høi Anseelse, Rusland og Nordamerika; og skiøndt den Ene, som et Despoti, førte Trælleaaget, den Anden, som en Republik, førte Frihedstræet i sit Vaabenskjold, saa bød de dog lige dumdristig Folkehistorien 
Trods, som selvgjorte Stormagter, ei af Guds Naade, men af forvovne Kroppe, uden fælles Fortid, Skæbne, Aand og Tungemaal (US VII, 695).

Naturalismen er ugudelig og åndløs. Den hævder det ideal, at mennesker skal tvivle om alt. Den er på den måde både moralsk og samfundsmæssigt opløsende og undergravende. Den har ifølge Grundtvigs verdenshistoriske tillæg en falsk opfattelse af godheden og kærligheden. Kærligheden opfattes i naturalismen kun som en individualistisk kærlighed. Naturalisten kalder sig en menneskeven og tror, at kærligheden kan komme fra det naturlige menneskes medfødte natur. Ifølge naturalismen skal vi elske hele verden og alle mennesker, uanset om de er kristne eller ukristne. Naturalismen hævder, at alle mennesker er ligestillede og uafhængige individer.

Ifølge Grundtvigs verdenshistorie hævder naturalisterne, at de er og har ret til at være deres egne fædre og mestre. Deres åndløshed viser sig for ham netop $\mathrm{i}$, at de vil være deres egne herrer, og på den måde afslører de deres ukærlighed og mangel på ærbødighed og respekt. Naturalismen undergraver det gode traditionelle samfund, som Grundtvig anser for at udgøre kristendommens "Forudsætninger". Naturalismen opløser den samfundsmæssige orden og dens naturlige nedarvede bånd og forvandler det menneskelige samfund til en vrimmel af individer:

Sin aandelige, eller rettere sin aandløse Retning havde det attende Aarhundrede allerede ved sin Midte kiendelig røbet, og det var da Mesterskab i den Helvedes Kunst at undergrave al Tro, ved at giøre alting tvivlsomt, som om det var den eneste rette Vei til en grundig SandhedsErkiendelse. Ligefra Aarhundredets Begyndelse vrimlede der i Engelland af saadanne Fritcenkere, som enten aabenlyst bekæmpede Christendommen med alle dens Forudsætninger, eller stræbte som Naturalister at befrie Christendommen fra alt det Underfulde (Miraculøse) og Utrolige, der kastede Skygge paa den og forhindrede den fra (...) ved sin Kiærligheds Aande, at indtage hele Verden (US VII, 696-697).

Naturalismen er selvklogskabens og selvrådighedens ånd. Den er skepticistisk og hævder derfor som den franske filosof Descartes (15961650), at alle mennesker skal tvivle om alt. Naturalismen kan derfor aldrig på nogen måde være gavnlig, opbyggende eller opbyggelig. Den er hjerteløs og ukærlig. Naturalismen benægter værdierne i kærligheden, troskaben, hjerteligheden og loyaliteten imod de naturlige autoriteter. Naturalisterne bekæmper den gavnlige og naturlige faderlige statsmagt. De skriger på den individuelle frihed og på en beskyttelse af individet imod de postulerede overgreb fra den centrale statsmagt. Naturalismen er en slags trolddom eller ond ånd, som forfører, fortryl- 
ler og forvirrer det moderne menneske. Grundtvig bruger i verdenshistorietillægget fra 1869 Montesquieu, Rousseau og Voltaire som repræsentanter for tre former for naturalisme, nemlig en politisk, antropologisk og kritisk skepticistisk form:

Saaledes begyndte da Latinskolens møisommelige Efterligning af den hedenske Selvklogskab at bære sine Frugter, og de modnedes først hos Calvinisterne i Genf (Genève) og i Frankerig, men dog var det især fra Holland, den almindelige Tvivlraadighed udbasunedes som Lægedom for al menneskelig Daarskab (...) Tre berømte Franskmænd dele (...) Æren for at have frelst Verden fra Overtroens Mareridt og fremkaldt Oplysningens gyldne Morgenrøde (...) Charles Montesquieu, Jean Jaques Rousseau og Voltaire, blandt hvilke dog den Sidste efter hele Verdens Dom vandt Prisen, fordi den fortryllede Hjertet og dræbte derved Troens Foster i Moderslivet (US VII, 697).

Grundtvig anvender i 1869 tydeligt nok begreberne "Naturalisme" og "Rationalisme" som synonymer eller som refererende til de samme fænomener. Naturalismen blev udformet i sin højeste videnskabelige skikkelse "i Nordtydskland", altså hos filosoffen Immanuel Kant (1724-1804) i Königsberg. Men Grundtvig lægger i sin verdenshistorie især vægt på "Naturalismen" som en amoralsk og samfundsopløsende størrelse, og som sådan manifesterer naturalismen sig især i Nordamerika og i Frankrig. Naturalismens ånd viste sig for første gang for alvor ved det amerikanske oprør i 1776, som var en selvrådig benægtelse af værdierne i det traditionelle samfund. Det amerikanske forbund er en ahistorisk, naturstridig og unaturlig skabelse. Det er ikke noget ægte "Samfund", men en unaturlig vrimmel eller mængde af individer, som alle vil være uafhængige og løsrevne af staten og samfundet. De amerikanske oprørere vil kun adlyde én eneste vilje, nemlig deres egen vilje:

Vel var det nu hverken i Frankerig eller i Engeland, men i Nordtydskland, at Naturalismen blev videnskabelig udarbeidet til det attende Aarhundredes berømte Rationalisme eller Fornuftlære; men dog blev den aldrig saa levende og saa frugtbar, som i Frankerig, hvor den i Slutningen af Aarhundredet virkelig øvede den Heltegierning at løse alle Hjertebaand og vise Verden, hvad en selvraadig Fornuft turde vove, og hvad en tøilesløs Frihed kunde udrette. Stødet til denne franske Omveltning (Revolution) kom imidlertid fra den ny Verden, hinsides den spanske Sø, i Nordamerika, hvor mange fribaarne og selvraadige Engelskmænd i Løbet af det syttende Aarhundrede havde nedsat sig og stiftet smaa Samfund, der kun lød deres egne Love (US VII, 697).

Naturalismens sejr i Frankrig i 1790'erne medførte en fuldstændig opløsning af alle moralske, politiske og samfundsmæssige idealer og 
værdier. Fra Frankrig udgik i 1790'erne "det forfærdelige Budskab" om, at alle standsforskelle var udslettet og ophævet. Grundtvigs tanke i verdenshistorie-tillægget fra 1869 er, at hvis alle samfundsmæssige bånd, alt hierarki og al social orden opløses, vil ukærligheden, tøjlesløsheden, hensynsløsheden og umoralen brede sig. Slagordene om frihed, lighed og broderskab opløser alle bånd og begrænsninger og nedriver alle kærlige bånd mellem mennesker. Kravet om frihed, lighed og broderskab ender nødvendigvis i despotiet og det moralske forfald. Den franske revolution fører med logisk nødvendighed til en ophævelse af den moralske disciplinering af de kropslige lyster og til en dyrkelse af den tøjlesløse seksualitet. Naturalismen har en falsk opfattelse af og tillid til det naturlige og derfor underminerer naturalismen den nødvendige moralske impuls- og selvkontrol:

"Frihed, Lighed og Broderskab," som under Krigen havde været Løsenet i Nordamerika, det blev nu, med de hjemkomne franske Hjelpetropper, Løsenet i Frankerig, og allerede i det næste Aartiende ${ }^{27}$ (17901800) gienlød over Europa det forfærdelige Budskab fra Frankerig, at der var baade Christendommen og al Standsforskiel afskaffet, der herskede de Buxeløse (Sansculotterne) ${ }^{28}$ med Uhyret Robespierre i Spidsen, og der hyldede man aabenlyst en Skiøge som Fornuftens Gudinde (US VII, 698). ${ }^{29}$

\section{Forskningen vedrørende Grundtvig og naturalismen}

Forholdet mellem Grundtvig og naturalismen har spillet en afgørende rolle i Kaj Thanings Grundtvig-forskning. ${ }^{30}$ De thaning'ske fortolkninger af Grundtvigs forhold til naturalismen har udøvet en afgørende indflydelse i Grundtvig-forskningen og i det almene Grundtvig-billede siden 1960'erne og har i deres grundstruktur inspireret en lang række

${ }^{27}$ Formen "Aartidende" på anførte side er i forhold til originaltrykket fra 1869 en trykfejl, som udgiveren H. Begtrup har overset i US VII.

${ }^{28}$ Grundtvig oversætter det franske ord (om dem fra borgerskabet, som bar lange bukser og ikke knæbukser og silkestrømper som adelen) med "de Buxeløse". Oversættelsen får de borgerlige franske frihedsmænd til at fremstå som respektløse, usømmelige, grænseoverskridende og anstødelige.

${ }^{29}$ Der er en forbløffende lighed mellem Grundtvigs vurderinger af naturalismen i hans verdenshistoriske værker i 1817 (jf. ovenfor) og 1869 på trods af den mellemliggende tidsafstand af 52 år og på trods af de mellemliggende dramatiske politiske omvæltninger som for eksempel enevældens fald i Danmark i 1848 !

${ }^{30}$ Jf. for eksempel Thaning 1963, 530, 610-618, 748-751, 766 og 773. 
af Grundtvig-forskere. ${ }^{31}$ Ifølge Kaj Thaning gennemgik Grundtvig i vinteren 1831-32 en "omvendelse", der førte ham frem til en moderne og sekulariseret holdning til vilkårene for den almindelige samfundsmæssige og kulturelle debat:

Hviler kulturkampen virkelig her på "hedensk" grundlag? Er der her tale om samarbejde med ikke-kristne? Ja, efter Grundtvigs mening (...) Naturalisterne er efter hans syn ikke kristne (...) Sammen med dem vil han bekæmpe ethvert umenneskeligt syn som f. eks. det gennemført biologiske syn på mennesket (Thaning 1966, 75).

Fra 1832 er Grundtvig villig til at indgå $i$ en fordomsfri dialog med $i$ princippet næsten alle mennesker, uanset om de er kristne eller ikkekristne. Grundtvig henvender sig efter Thaning ikke blot til sine rationalistiske præstekolleger i statskirken, men til alle anderledes tænkende i samtiden. Grundtvig făr en forståelse af, at en samtale og et samarbejde består af to parter, som hver på en ligeværdig måde bidrager med sine synspunkter, og som i fællesskab opnår en højere indsigt og et højere fælles gode:

Det nye er hans bevidst positive holdning over for tidens hedninger med ånd, når det gælder kulturkampen (...) Hans nye sondring mellem rationalisme og naturalisme (med ånd) er af afgørende betydning. At der er ånd uden for kirken er en erkendelse, der er et med sekulariseringen af 1832 (Thaning 1966, 76). ${ }^{32}$

Thaning fremhæver, at der ikke kun er tale om, at Grundtvig i 1832 beder nogle af naturalisterne om støtte til sit eget oldnordiske eller gammeldanske projekt. Grundtvig er indstillet på en åben samtale, og han anerkender, at naturalisternes synspunkter er legitime og gyldige som bidrag til den nødvendige fælles enighed, forhandling og løsning:

Han ønsker (...) brændende (...) at være i levende vekselvirkning med verden - $\mathrm{i}$ kulturelt samarbejde med "Folk med Aand" (...) en menneskeforklaring ud fra bevidstheden om mennesket som en gåde (...) han går [ind] $\mathrm{i}$ et frit samarbejde med naturalisterne (...) Det er en radikal vending (omvendelse). (Thaning 1966, 88-89)

${ }^{31}$ Eksempler: Bugge (1965, 1968, 1983, 2006), Elbek (1975), Jensen (1977), Grell (1980, 1988a, 1988b, 1992, 1995, 1998), Allchin (1997), Christensen (1998, 2001), Stokholm (2003) og Pedersen (2005).

${ }^{32}$ Thyssen 1991, 172 afviser, at Grundtvig i 1832 skulle have antaget en sekulariseret tankegang. "Linierne i Nordens Mythologi (...) tyder ikke på et dybtgående brud". Grundtvig går ifølge Thyssen ikke ind for to slags lys eller oplysning. Han regner kun med ét lys i denne verden, nemlig "den hellige Lampe i Ebræernes Tabernakel" (174). 
Thaning finder Grundtvig indstillet på en fri og åben dialog, og Grundtvig forudsætter eller kræver ikke, at naturalisterne skal acceptere specifikke kristne forestillinger for, at en samtale kan komme i stand. I 1832 opgiver Grundtvig tanken om, at det er nødvendigt, muligt eller legitimt at anvende eller gennemtvinge særlige kristne normer i den almenmenneskelige sfære:

Grundtvig udelukker efter Helge Grells mening ethvert menneskeligt og folkeligt fællesskab med mennesker, som fornægter enhver tale om et menneskeslægtens syndefald. Efter min mening er Grundtvig mere liberal (...) I dag ville vi vel i stedet tale om, at livet ikke er harmonisk, der er noget galt, tingene går ikke op eller lignende (Thaning 1988, 57).

Fra 1831-32 skelner Grundtvig ifølge Thaning skarpt mellem rationalisme og naturalisme. Grundtvigs omvendelse betyder, at han indser, at han selv er en af naturalisterne, og at han grundlæggende deler eller kan dele deres værdier, hvis de ikke har en materialistisk eller reduktionistisk anskuelse. Det menneskelige og verdslige har nu for Grundtvig en immanent værdi, uanset om det er kristent eller ej. Thaning taler om Grundtvigs nye

åndelige livssyn. Dette blev i 1832 skilt ud fra troen, idet Grundtvig så, at man kunne dele det med "Folk med Aand", tidens naturalister, som han nu adskilte fra rationalisterne. Deraf udviklede sig så efterhånden den skarpe adskillelse af det menneskelige og det kristelige (Thaning 1963, 748).

Den almene kulturdebat skal, som Grundtvig forstår den, fremme det levende, menneskelige, folkelige, danske og nordiske, og disse grundtvigske begreber fortolker Thaning som almene værdier, der ikke er defineret på forhånd, men skal afgøres i en fælles forhandling:

I modstrid med Grundtvigs formulering gør Aronson (...) syndefaldet til stridspunkt i forholdet til naturalisternes tro (...) Men (...) det er på menneskelig og folkelig, dansk og nordisk grund, den fælles kamp føres for livet mod døden. Men altså uden kristent fortegn (Thaning 1963, 749).

Grundtvig [fik] under opgøret med sin bodskristne fortid i lyset af den kristne tro det timelige liv at se som et hedensk-menneskeligt liv, der kunne leves uden bekymring for evigheden - i daglig kamp for det levende mod det døde (Thaning 1963, 766).

I 1831-32 opgiver Grundtvig sin hidtidige pietistiske kristendomsopfattelse, sin hidtidige fordømmelse af verden og sin hidtidige tanke om skellet mellem de sande kristne og verdens børn. Grundtvig bliver 
naturalist, og han finder sig selv og sin identitet i denne solidaritet med naturalismen:

I vinteren 1831-32 når han frem til at skelne mellem rationalisme og naturalisme. Gennem sin sidste omvendelse kommer han til at forstå sig selv - og ved at godkende sin egen naturalisme ${ }^{33}$ når han til videnskabeligt forlig med Clausen. Vi har set, hvordan han under sin omvendelse har været optaget af at stifte forlig til alle sider, hvor han har gjort uret, men først gjaldt det hans store kirkelige modstander (Thaning 1963, 265).

Thaning beskæftiger sig indgående med Grundtvigs forhold til naturalisterne i indledningen til Nordens Mythologi og drager en række konklusioner vedrørende Grundtvigs forhold til naturalismen, men han tager ikke det righoldige materiale i betragtning, hvor Grundtvig ellers i forfatterskabet forholder sig til begrebet naturalisme. Den eneste undtagelse herfra er, at Thaning kort behandler Grundtvigs artikel om den tyske teologi fra 1837. Thaning hævder, at Grundtvigs forhold til naturalismen undergår en fuldstændig forvandling i 1831-32, men han undersøger ikke eksplicit, om en sådan postuleret omvendelse skulle have sat sig konkrete spor i de mange værker, som Grundtvig skrev i årene efter 1832. Thaning fremlægger ingen beviser for, at Grundtvig selv på noget tidspunkt efter 1832 har refereret tilbage til en slags omvendelse i 1831-32. Thaning undersøger heller ikke det centrale spørgsmål, om der er en tydelig forskel på Grundtvigs vurderinger og beskrivelser af naturalisterne i 1832 sammenlignet med hans forfatterskab forud for 1832 .

Den lange række af eksempler i denne afhandling på, hvordan Grundtvig i sit samlede forfatterskab forholder sig til naturalismen, figurerer ikke $\mathrm{i}$ Thanings analyser af de forholdsvis få udtalelser om naturalisterne fra indledningen til Nordens Mythologi, 1832. Grundtvig kritiserer naturalismen ud fra et moralsk og politisk synspunkt. Den gennemgående og hyppige naturalismekritik hos Grundtvig forekommer ikke hos Thaning, der ser Grundtvig som modstander af et reduktionistisk, mekanicistisk eller biologistisk menneskesyn, men bortset herfra kan siges at indse, at han selv faktisk er en af naturalisterne og derfor naturligt nok kan have en helt åben samtale og et fordomsfrit samarbejde med dem.

En række forskere har især siden 1960'erne fremført fortolkninger af Grundtvig og naturalismen, som er beslægtede med Thanings

${ }^{33}$ Thaning 1963, 610: Grundtvig "vedkender sig sit fællesskab med dens [naturalismens] åndelige livssyn". 
fortolkninger. Det gælder især K. E. Bugge, ${ }^{34}$ Helge Grell ${ }^{35}$ og Kim Arne Pedersen. ${ }^{36}$ Som et eksempel kan anføres K. E. Bugges fortolkning fra 1983. Han fremhæver, at Grundtvig gennemgår en omvendelse i 1832, der resulterer i en lettelse og befrielse:

Grundtvig drager den konsekvens (...) at kristne og naturalister må kunne holde skole sammen (...) Grundtvigs særlige opfattelse af forholdet mellem menneskeligt og kristeligt gav ham og hans meningsfæller en inspirerende frihed til på skolens område at samarbejde med anderledes tænkende. Den gav ham en bemærkelsesværdig frihed til at se bort fra specifikt kristne trosforestillinger (Bugge 1983, 212-213).

De grupper eller personer, som Grundtvig ifølge Bugge på det samfundsmæssige område er imødekommende over for og villig til åbent at samarbejde med, er i princippet alle, som er "anderledes tænkende" i forhold til Grundtvig i al fald, hvis de ikke har et "mekanistisk" menneskesyn. Bugge fortolker Nordens Mythologi på en sådan måde, at det ser ud, som om Grundtvig taler til og udtrykker sit håb om alle naturalister i Norden eller i Danmark:

Tro er tanker eller forventninger, der efter kristen opfattelse er snævert bundet til Kristi person og gerning. Anskuelse, derimod, er et livs- og menneskesyn, som kristne kan have tilfælles med folk, som Grundtvig kalder "Naturalister" (Bugge 1983, 212).

Også i sin disputats fra 1965 skriver K. E. Bugge, at Grundtvig i 1832 fremsatte et forligstilbud til alle danske eller nordiske naturalister, og at Grundtvig i 1825 og i 1832 opnåede en ny frihed til at kunne se bort fra sine egne religiøse forestillinger, når han tog del i den almindelige samfundsmæssige debat:

Derpå havde også "opdagelsen" i 1825 fritaget ham for at skulle pånøde noget i sig selv ejendommeligt et kristeligt skin. En ganske særlig

${ }^{34}$ Bugge 1965, 268, 311 og 367, Bugge 1968, I, 22, Bugge 1983, 212, 213 og 214, Bugge 2006, 53, 54 og 62. Bugge baserer sin analyse af relationen mellem Grundtvig og naturalismen på indledningen til Nordens Mythologi. Grundtvigs mange øvrige udsagn i forfatterskabet om naturalismen inddrages ikke. De steder, hvor Bugge i sine værker har diskuteret Grundtvigs forhold til naturalisterne, har han især fokuseret på Grundtvigs tanker om et samarbejde med naturalisterne på det uddannelsesmæssige område.

${ }^{35}$ Grell 1988b, 97 og Grell 1992, 147, 152, 163, 168 og 169. Grell har dog en række kritikpunkter mod Thaning og afviser tanken om, at Grundtvig nogen sinde skulle give udtryk for en sekulariseret tankegang. Jf. for eksempel Grell 1988b, 97-98.

${ }^{36}$ Andre eksempler er: Elbek 1975, 36, Jensen 1977, 75-76, Stokholm 2003 og Balslev-Clausen 1990, 53-54. 
akcentuering fik disse tanker imidlertid for Grundtvig som følge af hans gennembrud i 1831/32, hvorunder han stødte frem til sondringen mellem tro og anskuelse og på dette grundlag kunne tilbyde naturalisterne "Forlig" (Bugge 1965, 310-311).

Bugge synes i sine fortolkninger at overse flere ting, som fremgår af indledningen til Nordens Mythologi. Dels taler Grundtvig i 1832 ikke eksplicit til alle naturalister, men kun til en mindre gruppe af naturalister, nemlig dem, som - på trods af deres naturalisme - måske alligevel kan handle med "Aand", og dels udtrykker Grundtvig ikke direkte et ønske om en åben eller fordomsfri dialog, men mere præcist et håb og en bøn om, at nogle af naturalisterne - på trods af deres naturalisme - måske alligevel vil understøtte de kristne i deres - altså $\mathrm{i}$ de sande kristnes - nationale projekt (jf. ovenfor). Man kan også indvende imod K. E. Bugges - og Thanings - fortolkninger, at der ikke findes et eneste sted i indledningen til Nordens Mythologi, hvor Grundtvig giver udtryk for, at han er lettet, glad eller tilfreds med, at han nu har opnået en hidtil for ham ukendt frihed $\mathrm{i}$ forhold til naturalisterne eller naturalismen.

En række Grundtvig-forskere har både før og efter 1960'erne givet analyser af forholdet mellem Grundtvig og naturalismen, som klart adskiller sig fra de thaning'ske fortolkninger. Det gælder Grundtvigforskere som Nørgaard (1935, 1936, 1938), Høirup (1949), Michelsen $(1956,1965,1972,1988)^{37}$, Aronson $(1960)^{38}$, Lindhardt (1964),

${ }^{37}$ Michelsen 1956, 232, 233, 288 og 289, Michelsen 1965, 52 og Michelsen 1988, 24 og 99. Michelsen 1988, 99: “'Moderne' var Grundtvig bestemt ikke (...) Grundlaget for hans tanker var ikke moderne; det var kristent - ikke en moderniseret, men en ægte, oprindelig kristendom. Han var modstander af materialisme, rationalisme og naturalisme". Michelsen 1956, 288-289: Naturalismen "har fået farlige konsekvenser (...) i dens eftervirkninger i dansk åndsliv". Et billede på den naturalisme, som Grundtvig angriber, finder man i Kaj Munks skuespil En Idealist fra 1928. Denne farlige naturalisme finder man ifølge Michelsen 1956, 289 også i Søren Kierkegaards tænkning.

${ }^{38}$ Aronson 1960, 57, 58, 59, 85, 86, 87 og 88. Aronsons opfattelse af Grundtvigs forhold til naturalismen bliver voldsomt kritiseret i Thaning 1963, 748, 749 og 773. Aronson 1960, 57, 85 og 86: Grundtvig var endnu mere krigerisk og konfronterende over for naturalisterne i 1832 end i 1825 (jf. Thyssen 1991, 85). Grundtvigs anliggende i Nordens Mythologi var at skabe afstand og sætte skel $\mathrm{i}$ forhold til naturalisterne og ikke at søge samtale eller forsoning. Aronson 1960, 58, 59, 86-88: Grundtvig angriber i Nordens Mythologi naturalisterne for at have en unaturlig og naiv tillid til det naturlige menneskes muligheder. Mennesket er grundfordærvet og besmittet af synden i sine tanker, følelser, gerninger, indbildningskraft og erkendelse. Det naturlige ikke-kristne menneske er ifølge Grundtvig fortabt i et mørke og kan ikke ved egne kræfter 
Thyssen (1965, 1967, 1991), Prenter (1983) og Vind (1999). ${ }^{39}$ Selv om man hos disse forskere finder forskellige vurderinger af Grundtvigs forhold til naturalismen, er de alligevel samlet set udtryk for en vis tendens. Som et eksempel kan nævnes P. G. Lindhardts vurdering fra 1964:

Begge [både Grundtvig og naturalisterne] kan på det naturliges græsknordiske grund bekæmpe "døden" i romersk og tysk kulturs skikkelse (...) menneskeligt og borgerligt burde der skabes en "kulturel foellesfront" (...) Men hans [Grundtvigs] forsøg på at komme på talefod med romantikerne eller H. N. Clausen fandt ikke genklang; "fredsbetingelserne" var uantagelige (Lindhardt 1964, 80-81).

Lindhardt fremhæver, at Grundtvigs såkaldte tilbud til naturalisterne i 1832 var farvet og betinget af Grundtvigs egne værdier. Ifølge Lindhardt fremsatte Grundtvig et tilbud til naturalisterne, som havde en sådan karakter, at de umuligt kunne gå ind på forslaget og dets præmisser. Grundtvig opfordrer naturalisterne til at gå ind i en "fællesfront" - Lindhardt tænker måske på de politiske fællesfronter fra 1930'erne - mod en fjende, som naturalisterne dybest set ikke opfatter som en fjende. ${ }^{40}$ Ifølge Lindhardts fortolkning viser Grundtvig ikke nogen virkelig imødekommenhed eller samarbejdsvilje over for naturalisterne. Grundtvig er mest optaget af at definere sine egne værdier både kristeligt og folkeligt eller samfundsmæssigt. ${ }^{41}$

Det synspunkt, at Grundtvig i 1832 ikke viser nogen særlig imødekommenhed over for naturalisterne, og at han i Nordens Mythologi

erhverve sig en sand erkendelse af virkeligheden. Aronson 1960, 59: Grundtvig havde bestemt ikke "en flackt optimistisk människosyn". Jf. Michelsen 1965, 52: Grundtvigs menneskesyn er "ikke et sækulariseret (...) humanistisk menneskebegreb, men kristendommens opfattelse af mennesket som skabt i Guds billede, fristet af djævelen og faldet for fristelsen".

${ }^{39}$ Jf. også Gregersen 2002, 18: "Det er næppe rigtigt at tolke Grundtvigs erkendelsesteori i forlængelse af den engelske empirisme (...) eller [Grundtvig] som en slags foregangsmand for en realistisk naturalisme".

${ }^{40}$ Jf. også den skarpe afvisning af Grundtvigs kulturelle program fra kultusminister J. N. Madvig (1804-1886) den 9. december 1848 i den grundlovgivende forsamling. Jf. Michelsen 1991, 52 og Bjørn 2007, 74-76.

${ }^{41}$ Jf. en tilsvarende vurdering hos Thyssen 1967, 48: Grundtvig "tænkte kun på kultur-samarbejde med (...) præster og teologer, som (...) fastholdt 'den mosaisk-kristelige anskuelse". Jf. Aronson 1960 og Michelsen 1988, 99. Thyssen 1991, 79 citerer et brev af 29. oktober 1831, hvor Grundtvig forklarer, at han nu endegyldigt - efter at have studeret mange bøger om naturalismen - har gennemskuet og derfor taget afstand fra naturalisterne og al slags naturalisme. 
mest bruger pladsen på at understrege de dybe uforenelige modsætninger mellem sin egen og naturalisternes opfattelse, har spillet en vigtig rolle hos en række forskere. ${ }^{42}$ Det er også blevet fremhævet nogle steder i forskningen, at Grundtvig - hvis han overhovedet i 1832 har været indstillet på et samarbejde med naturalisterne - hurtigt opgiver denne tanke efter $1832 .{ }^{43}$ I den forbindelse kan man også fremføre et moment, som ikke er blevet nævnt i Grundtvig-forskningen, nemlig, at en analyse af Grundtvigs værker i de år, som følger umiddelbart efter 1832, ikke viser noget spor af, at Grundtvig skulle have erhvervet sig en ny "befriende" eller "inspirerende" (Bugge) opfattelse af naturalismen og ikke indeholder et eneste eksempel på, at Grundtvig viser nogen venlig imødekommenhed over for naturalisterne.

Det indgår som et vigtigt moment i den thaning'ske fortolkning af Grundtvigs omvendelse til virkeligheden i 1831-32, at Grundtvig fra det tidspunkt skarpt adskiller og modstiller begreberne om "Naturalisme" og "Rationalisme". Det er netop denne adskillelse, som ifølge Kaj Thaning og K. E. Bugge gør det muligt for Grundtvig at acceptere det naturlige, verdslige og jordiske og dermed samarbejde med naturalisterne. ${ }^{44}$ Men hvis man undersøger, hvordan Grundtvig rent faktisk i sine skrifter behandler de to begreber, viser der sig et andet billede. Der er ikke fundet et eneste eksempel fra Grundtvigs forfatterskab på, at han klart eller udtrykkeligt adskiller eller modstiller de to begreber "Naturalisme" og "Rationalisme", og der er heller ikke fundet et eneste eksempel på, at Grundtvig skriver, at en sådan adskillelse skulle være vigtig for hans egen holdning til eller vurdering af naturalismen. ${ }^{45}$

42 Jf. de anførte referencer til Aronson. Jf. også Thyssen 1965, 104, Thyssen 1967, 48, Thyssen 1988, 49 og Thyssen 1991, 79, 86, 105, 168, 170, 171, 172 og 183.

43 Jf. Thyssen 1991, 169: Grundtvig anvender i Nordens Mythologi formuleringer, "der snarere peger tilbage mod 1810 og 1825 end mod den påståede 'omvendelse til menneskelivet' i 1832. Alle Grundtvigs overvejelser i Nordens Mythologi forudsætter i virkeligheden det kristendomssyn, han allerede var nået frem til".

${ }^{44}$ Thaning 1963, 265, 748 og 749, Thaning 1966, 76 og Bugge 2006, 62.

${ }^{45}$ Grundtvig anvender både før og efter 1832 "Naturalisme" og "Rationalisme" som synonymer eller som refererende til de samme fænomener. Jf. for eksempel: US VII, 697 (fra 1833), US VIII, 162-163 (fra 1837), US VII, 593-594 (fra 1843). Et eksempel fra før 1832 er: US V, 56-57 (fra 1827). Ordbog over det danske Sprog XIV (1933) oversætter i artiklen "Naturalisme" ordet med "rationalisme" og i artiklen "Naturalist" med "rationalist". Ordbogen citerer også H. L. Martensen (1808-1884) for i sin dogmatik fra 1849 at have erklæret: "Naturalisme og Rationalisme ere tvende Sider af det Samme". Jf. Nør- 
William Michelsen og Anders Nørgaard har forsøgt at tegne et bredt billede af Grundtvigs forhold til naturalismen. Nørgaard beskriver de store linjer i Grundtvigs og $\mathrm{i}$ den senere grundtvigianismes forhold til naturalismen og fremhæver, at Grundtvig hele sit liv bekæmpede naturalismen, men at grundtvigianismen i høj grad efter Grundtvigs død blev inficeret af den moderne liberale, humanistiske og naturalistiske ånd. ${ }^{46}$ Nørgaard henviser dog ikke til konkrete tekster af Grundtvig. ${ }^{47}$ De eksempler på Grundtvigs vurderinger af naturalismen, som blev gennemgået ovenfor, synes at vise, at Nørgaards synspunkter fra 1930'erne i høj grad og i al fald på det generelle plan er dækkende vedrørende Grundtvigs forhold til naturalismen.

Det er bemærkelsesværdigt, at der ikke i Grundtvig-forskningen er fundet et eneste tydeligt eksempel på, at Grundtvigs opfattelse af naturalismen sammenkædes med en moralsk holdning til den, endsige en fordømmelse. Det er ligeledes bemærkelsesværdigt, at der i Grundtvig-forskningen kun findes ganske få eksempler på, at Grundtvigs opfattelse af naturalismen kædes sammen med en specifik samfundsopfattelse hos Grundtvig. ${ }^{48}$ Disse to forhold er overraskende ud fra de eksempler på Grundtvigs anvendelse af begreberne "Naturalisme", "Naturalister" og "naturalistisk", som blev analyseret ovenfor.

gaard 1936, 97: Hos Grundtvig dækker "Rationalisme" og "Naturalisme" de samme fænomener.

${ }^{46}$ Nørgaard 1936, 88, 95 og 97 og Nørgaard 1938, 25 og 134.

${ }^{47}$ Jf. Michelsen 1972, 20 om naturalismen (og brandesianismen) og Grundtvig som uforenelige antiteser. Michelsen fremhæver ligesom Nørgaard, at Grundtvig hele sit liv bekæmpede naturalismen, men ligesom Nørgaard henviser Michelsen ikke til konkrete Grundtvig-citater. Jf. for eksempel Michelsen 1988, 99. Ifølge Nørgaard 1936, 88, 95 og 97 blev brandesianismen, humanismen, liberalismen og naturalismen en alvorlig fristelse for og trussel mod og en slags underminerende muldvarp inden i den grundtvigske bevægelse i tiden 1872-1900. Nørgaard 1936, 97: Naturalismen medvirkede "til at fortynde Frihedsforstaaelsen" hos grundtvigianerne. "Her mødtes" Grundtvigs "Anskuelse af Menneskelivet med en naturalistisk-rationalistisk. Den første var uendelig dybere end den sidste. Men den sidste var glimrende og blændende. Og den virkede blændende langt ind i Grundtvigianernes Lejr".

${ }^{48}$ Vind 1999, 432, 477, 483 og 560-561. Bugge 1965, 268 diskuterer den mulighed, at Grundtvigs holdning til naturalismen eventuelt kunne være præget af en antiliberal holdning. Jf. også Bugge 1983, 213 og 215, som nævner den franske julirevolution $1830 \mathrm{og}$ det danske reskript om de rådgivende stænderforsamlinger fra 1831. Men Bugge sammenkæder ikke Grundtvigs forhold til disse begivenheder med Grundtvigs holdning til naturalismen i indledningen til Nordens Mythologi fra 1832. 


\section{Konklusion}

Det blev tidligere nævnt, at Grundtvig i al fald ved sin død ejede et eksemplar af den tyske teolog J. G. Walchs filosofiske leksikon, og at begrebet naturalisme bliver defineret i dette opslagsværk, som oprindeligt udkom i 1726. Men hvis man undersøger de tekststeder i Grundtvigs forfatterskab, hvor ordene "Naturalisme", "naturalistisk" og "Naturalister" optræder, findes der ingen steder nogen reference til en bestemt naturalisme-definition hverken hos Walch eller nogen anden forfatter. I det hele taget synes det tvivlsomt, om Grundtvig i sine tekster gik ud fra en detaljeret definition på begrebet naturalisme, og det synes ligeledes tvivlsomt, om Grundtvig i sine tekster selv søgte at levere en egentlig definition på begreberne om naturalismen. Snarere bærer Grundtvigs tekster præg af, at han anvender eller udnytter ordene "Naturalisme", "naturalistisk" og "Naturalister" i sine stærkt følelsesladede angreb på bestemte politiske, moralske, filosofiske og kristelige synspunkter, som han fandt helt fejlagtige. Ved at undersøge Grundtvigs faktiske brug af begreberne om naturalismen kan man altså få et alment indblik i hans synspunkter vedrørende en bred vifte af problemstillinger.

Grundtvig vurderede i 1830 'erne, at de traditionelle gammeldanske kulturværdier var truet, og at denne trussel først og fremmest kom fra den stadigt voksende naturalisme, som virkede undergravende for den folkelige dannelse og opdragelse og for statens sammenhængskraft. I en artikel i 1834 talte Grundtvig på den måde om sin "Drøm" om "Statens aandelige Varighed":

Det er en Drøm, vil sagtens mange sige, en Drøm, som hele min Anskuelse af Folkelig Dannelse og Statsmoessig Oplysning; men naar Man indseer, at i saa Fald er ogsaa Folke-Livets Fortsættelse og Statens aandelige Varighed kun en Drøm, da vil dog vist alle ægte Danne-Mænd og Danne-Kvinder dele den Følelse hos mig, at Drømmen er alt for sød og den modsatte Virkelighed alt for bitter til at Man godvillig skulde giøre et Bytte (Citeret i Bugge 1965, 267-268).

Grundtvig bekæmpede i hele sit forfatterskab naturalismen. Alle de steder, hvor han anvendte begreberne "Naturalisme", "Naturalist" og "naturalistisk", brugte han dem i en negativ betydning. Hans indledning til Nordens Mythologi fra 1832 synes ikke at udgøre en undtagelse fra denne regel. I sin vurdering og forkastelse af naturalismen lagde han de fleste steder stor vægt på dens negative moralske og samfundsmæssige eller politiske egenskaber. Naturalismen er den umoralens, ukærlighedens, selvklogskabens, oprørskhedens og selvrådighedens hjerteløse ånd, som truer de traditionelle kristne samfund og stater i det 19. århundrede. På trods af eller måske netop i kraft af 
dyrkelsen af, troen på og tilliden til det naturlige og det naturlige menneske, bliver naturalismen ifølge Grundtvig både urealistisk, naiv, falsk, skadelig og unaturlig.

\section{Forkortelser}

US I-X: Begtrup, Holger (udg.) (1904-09), Nik. Fred. Sev. Grundtvigs Udvalgte Skrifter, I-X, København.

\section{Litteraturliste}

\section{Voerker af Grundtvig}

Begtrup, Holger (udg.) (1904-09), Nik. Fred. Sev. Grundtvigs Udvalgte Skrifter, I-X, København.

\section{Voerker af andre forfattere}

Allchin, A. M. (1997), N. F. S. Grundtvig. An Introduction to His Life and Work, Aarhus.

Aronson, Harry (1960), Mänskligt og kristet, en studie i Grundtvigs teologi, Stockholm.

Balslev-Clausen, Peter (1990), "Verdenssyn og menneskesyn i Grundtvigs salmedigtning" i Grundtvig-Studier 1989-90, København, 46-65.

Bjørn, Claus (2007), Grundtvig som politiker. København.

Borchsenius, Otto, og Horn, Fr. Winkel (udg.) (1884), Peter Andreas Heibergs Udvalgte Skrifter, København.

Bugge, K. E. (1965), Skolen for livet. Studier over N. F. S. Grundtvigs padagogiske tanker, København.

Bugge, K. E. (udg.) (1968), Grundtvigs skoleverden i tekster og udkast, I-II, København.

Bugge, K. E. (1983), "Grundtvigs pædagogiske tanker" i Thodberg, Christian og Anders Pontoppidan Thyssen (udg.) (1983), Grundtvig og grundtvigianismen i nyt lys, København, 210-224.

Bugge, K. E. (2006), "En upåagtet dimension i Grundtvigs tanker om 'Anskuelsen"” i Grundtvig-Studier 2006, København, 53-66.

Christensen, Bent (1998), Omkring Grundtvigs Vidskab. En undersøgelse af NFS Grundtvigs forhold til den erkendelsesmoessige side af det kristeligt nødvendige livsengagement, København.

Christensen, Bent (2001), "Om 'Omkring Grundtvigs vidskab"' i GrundtvigStudier 2001, København, 191-220.

Ehnevid, Tord (1973), "The Dominant peoples in History according to Grundtvig and Hegel" i Grundtvig-Studier 1973, København, 115-127.

Elbek, Jørgen (1975), "Deltheden hos Grundtvig efter 1832" i GrundtvigStudier 1975, København, 33-38. 
Fortegnelse over den af N. F. S. Grundtvig efterladte Bogsamling (1873), København.

Gregersen, Niels Henrik (2002), "Når der bliver mere ud af mindre: Grundtvigs menneskesyn" i Wigh-Poulsen, Henrik m. fl. (red.) (2002), Grundtvig-Kierkegaard, en samtale på høje tid. København, 11-30.

Grell, Helge (1980), Skaberordet og billedordet. Studier over Grundtvigs teologi om ordet, København.

Grell, Helge (1988a), Skaberånd og Folkeånd. En undersøgelse af Grundtvigs tanker om folk og folkelighed og deres forhold til hans kristendomssyn, København.

Grell, Helge (1988b), "Replik" i Schjørring, Jens Holger (1988), Menneske først, kristen så. Helge Grells Grundtvig-disputats til debat, Århus, 85-101.

Grell, Helge (1992), England og Grundtvig. Grundtvigs møde med England og dets betydning for hans forfatterskab, København.

Grell, Helge (1995), Grundtvig og Oxforderne. Grundtvigs møde med Oxfordbevagelsen og dets betydning for hans forfatterskab, Aarhus.

Grell, Helge (1998), Vision og virkeliggørelse. En redegørelse for Grundtvigs tanker om folkelig oplysning og en folkelig højskole og for forsøget på at virkeliggøre den, Aarhus.

Hansen, Niels Buur (1997), "Mennesket i verden, verden i mennesket" i Korsgaard, Ove (red.) (1997), En orm - en Gud. Om mennesket i verden, Odense, 41-62.

Heiberg, P.A., se Borchsenius.

Høirup, Henning (1949), Grundtvigs syn på tro og erkendelse. Modsigelsens Grundsæetning som teologisk Aksiom hos Grundtvig, København.

Iversen, Hans Raun (1988), "Folkelighed og kristendom" i Schjørring, Jens Holger (1988), Menneske først, kristen så. Helge Grells Grundtvig-disputats til debat, Århus, 67-84.

Jensen, Erik Krebs (1977): "Hjertets gudbilledlighed" i Thodberg, Christian (udg.) (1977), For sammenhoengens skyld. Aarhus, 65-96.

Lindhardt, P. G. (1964), Grundtvig, København.

Lundgreen-Nielsen, Flemming (1983), "Grundtvig og romantikken" i Thodberg, Christian og Anders Pontoppidan Thyssen (udg.) (1983), Grundtvig og grundtvigianismen i nyt lys, København, 19-42.

Lundgreen-Nielsen, Flemming (1995), "Grundtvig og guldalderens København" i Grundtvig-Studier 1995, København, 107-139.

Lundgreen-Nielsen, Flemming (2007), "Grundtvig og censuren" i GrundtvigStudier 2007, København, 44-90.

Michelsen, William (1956), Den scelsomme forvandling i Grundtvigs liv. Studier over tilblivelsen af Grundtvigs historiesyn, København.

Michelsen, William (1965), "Om Grundtvigs historiesyn" i Grundtvig-Studier 1965, København, 49-54.

Michelsen, William (1972), "Det moderne menneskes situation og Grundtvigs antropologi" i Grundtvig-Studier 1972, København, 9-22.

Michelsen, William (1988), "Om Grundtvig, Kierkegaard og det moderne gennembrud" i Grundtvig-Studier 1988, København, 96-99. 
Nørgaard, Anders (1935, 1936, 1938), Grundtvigianismen. Et historisk Bidrag, I-III. I: 1935, II: 1936, III: 1938, København.

Pedersen, Kim Arne (2005), "Grundtvig og fundamentalismen" i GrundtvigStudier 2005, København, 86-124.

Prenter, Regin (1983), Den kirkelige anskuelse. En indførelse i N. F. S. Grundtvigs folkelige og kristelige grundtanker, København.

Scharling, Carl Immanuel (1947), Grundtvig og Romantiken belyst ved Grundtvigs Forhold til Schelling, København.

Stokholm, Anja (2003), "Om forholdet mellem skabelse og syndefald hos Grundtvig og Luther" i Grundtvig-Studier 2003, København, 88-125.

Thaning, Kaj (1963), Menneske først - Grundtvigs opgør med sig selv, I, II og III, København.

Thaning, Kaj (1965), "Svar til tre kritikere" i Grundtvig-Studier 1965, København, 55-89.

Thaning, Kaj (1966), “Holdt tesen?” i Grundtvig-Studier 1966, København, 68-98.

Thyssen, Anders Pontoppidan (1965), "Skolen for livet. Anmeldelse af K. E. Bugges disputats" i Grundtvig-Studier 1965, København, 90-111.

Thyssen, Anders Pontoppidan (1967), "Grundtvig og Spener. Især til belysning af den pietistiske Grundtvig" i Grundtvig-Studier 1967, København, 9-50.

Thyssen, Anders Pontoppidan (1991), Grundtvig og den grundtvigske arv. Afhandlinger af Anders Pontoppidan Thyssen. Udgivet af Jakob Balling med flere, Aarhus.

Vind, Ole (1999), Grundtvigs historiefilosofi, København. 